\title{
Process Outgrowth and Synaptic Varicosity Formation by Adult Photoreceptors in vitro
}

\author{
James W. Mandell, ${ }^{1, a}$ Peter R. MacLeish,, ${ }^{1,2}$ and Ellen Townes-Anderson ${ }^{1,2}$ \\ 'Department of Physiology and Biophysics, and ${ }^{2}$ The Margaret M. Dyson Vision Research Institute, Department of \\ Ophthalmology, Cornell University Medical College, New York, New York 10021
}

To assess the regenerative capability of the photoreceptor synapse, we have isolated and cultured photoreceptors from the mature salamander retina. Both rod and cone photoreceptors were able to regenerate processes within $3 \mathrm{~d}$ of plating. Cells extended numerous actin-containing filopodia as well as a few neuritic processes. The neurites contained microtubules and formed synaptic vesicle-filled varicosities, as shown by immunostaining for tubulin and synaptic vesicle proteins and by electron microscopy. Furthermore, regenerated varicosities were capable of depolarization-induced vesicle labeling, suggesting that they can recycle synaptic vesicles and release neurotransmitter by synaptic vesicle exocytosis. Differences were observed between rod and cone cell synaptic regeneration in vitro, which resembled structural differences between their synaptic terminals in situr. rod cells formed multiple synaptic vesicle-filled varicosities along neurites at a distance from the soma, whereas cone cells tended to accumulate synaptic vesicles within the soma. The regeneration of neurites and synaptic vesiclefilled varicosities was abolished by microtubule depolymerizing agents, suggesting a role for microtubule-based vesicle transport in the formation of varicosities. Finally, process outgrowth and varicosity formation were independent of cellcell contact and, indeed, proceeded in the complete absence of other cells. These findings suggest not only that differentiated photoreceptors are capable of synaptic renewal but that the regeneration of presynaptic-like terminals is an intrinsic ability of rod and cone cells.

IKey words: photoreceptor, synapse, regeneration, synaptic vesicles, neurite outgrowth, synaptic plasticity, rod and cone cells]

A growing body of evidence indicates that mature neurons can remodel presynaptic terminals and generate new synapses. Activity-dependent changes in synaptic structure probably represent an important cellular basis for information storage in the nervous system (reviewed in Greenough and Bailey, 1988). Furthermore, many CNS neurons respond to injury by axonal sprouting and the formation of new presynaptic terminals (for

\footnotetext{
Received Aug. 10, 1992; revised Jan. 4, 1993; accepted Mar. 1, 1993.

This work was supported by NIH Grant EY06135 to E.T.-A. and NIH Grant EY05201 and a Research to Prevent Blindness Professorship to P.R.M. J.W.M. is the recipient of a Life and Health Insurance Medical Research Fund scholarship.

Correspondence should be addressed to Dr. Ellen Townes-Anderson, Department of Physiology and Biophysics, Cornell University Medical College, 1300 York Avenue, New York, NY 10021.

a Present address: Department of Neuroscience, University of Virginia School of Medicine, Charlottesville, VA 22908.

Copyright (C) 1993 Society for Neuroscience $0270-6474 / 93 / 133533-16 \$ 05.00 / 0$
}

reviews, see Cotman and Nieto-Sampedro, 1984; Greenough and Bailey, 1988; Steward, 1989; Aguayo et al., 1990). Evidence for both types of presynaptic structural plasticity has been provided largely by electron microscopic analyses of terminals within complex brain neuropil. Such studies, however, do not reveal details of the cellular dynamics leading to plastic changes, nor do they provide information about the signals that initiate these plastic phenomena and their intracellular mechanisms.

To address these issues, we have utilized an in vitro system in which the modification and regeneration of individual presynaptic terminals could be studied. Photoreceptors are highly polarized neurons whose morphology is dominated by two specializations at opposite ends of the cell: a photosensitive outer segment at the apical end of the cell and a large synaptic terminal at the basal pole, thought to release glutamate onto second-order neurons (Copenhagen and Jahr, 1989). Previous work demonstrated that salamander rod photoreceptors, obtained by enzymatic and mechanical dissociation of the adult retina, were light responsive (Bader et al., 1978) and that many retained functional presynaptic terminals (Townes-Anderson et al., 1985). Furthermore, both rod and cone photoreceptors could be maintained in culture under defined conditions and, after a period in vitro, were shown to form functional synaptic connections with postsynaptic cells (MacLeish et al., 1983; MacLeish and Townes-Anderson, 1988). In the present study, we have visualized presynaptic components with light microscopic immunocytochemistry and conventional clcctron microscopy. Our results indicate that mature photoreceptors, in the absence of any cell-derived external cues, are capable of extensive process outgrowth and regeneration of synaptic-like varicosities.

Portions of this work have been presented in abstract form (Mandell et al., 1988).

\section{Materials and Methods}

Primary antibodies. Antibodies to the synaptic vesicle proteins SV2 and synaptophysin (protein p38) were the generous gifts of Dr. K. Buckley (Harvard Medical School) and Dr. F. Valtorta (University of Milano, Italy), respectively. They have been previously characterized in neural tissues of other vertebrate species (Buckley and Kelly, 1985; Valtorta et al., 1988). Anti-opsin monoclonal antibody 4D2 was a gift of Dr. D. Hicks (INSERM, Paris); it has been shown in the frog to recognize a form of opsin specific to red rod photoreceptors (Hicks and Molday, 1986). To test antibody specificity in the salamander retina, immunoblotting was performed on whole retinal homogenates separated by SDSPAGE (not shown). The anti-SV2 monoclonal antibody and anti-synaptophysin polyclonal antiserum revealed single bands of 90 and 38 $\mathrm{kDa}$, respectively, consistent with the antigens recognized in other species and neural tissues. Antibody 4D2 recognized multiple bands of 34, 63,98 , and $126 \mathrm{kDa}$. This result is consistent with previous biochemical studies showing that opsin forms dimers, trimers, and tetramers even under the reducing conditions of SDS-PAGE (Molday and Molday, 
1979). A monoclonal antibody (5A6) against an algal tubulin but crossreactive to many species was kindly provided by Dr. K. Reuhl (Rutgers University).

Other labeling reagents. Fluorescein-phalloidin was obtained from Molecular Probes (Eugene, OR). Fluorescein- and rhodamine-conjugated goat anti-mouse or goat anti-rabbit secondary antibodies were obtained from Organon-Teknika/Cappel (Malvern, PA); $5 \mathrm{~nm}$ colloidal gold-conjugated protein $A$ or goat anti-mouse $\operatorname{IgG}$ was purchased from Amersham (Janssen Product Division).

Immunocytochemistry of intact retina. Light-adapted tiger salamanders (Ambystoma tigrinum), 12-20 cm in length, were decapitated and pithed. The eyes were removed and placed in salamander salt solution (Bader et al., 1978), and the anterior segments were cut away.

For light microscopic immunofluorescence, the resulting eyecup was fixed by immersion in $4 \%$ formaldehyde in $0.1 \mathrm{~m}$ phosphate buffer, $\mathrm{pH}$ 7.4 (PB), for 3-12 hr. Fixed retinas were removed from the eyecup, adherent pigment epithelium was removed, and the tissue was rinsed in PB. Thick $(40-70 \mu \mathrm{m})$ sections were prepared by flattening a whole fixed retina, receptor side up, on a Teflon surface and slicing with a Mcllwain tissue chopper. This method provided preservation of both outer segment and plexiform layer structure that was superior to that of cryoslat sections. Retinal slices were collected in PB and used immediately for immunostaining.

Immunolabeling was performed on free-floating sections in test tubes on a rotating platform as follows: (1) incubation in goat serum dilution buffer (GSDB; $450 \mathrm{mM} \mathrm{NaCl}, 17 \%$ goat serum, $0.3 \%$ Triton $\mathrm{X}-100,20$ mM sodium phosphate buffer, $\mathrm{pH} \mathrm{7.4)}$ for $30 \mathrm{~min}$; (2) incubation in primary antibody diluted in GSDB for 3-12 hr at room temperature [antibody dilutions: SV2 supernatant (Buckley and Kelly, 1985), 1:10; rod-specific monoclonal antibody (P. R. MacLeish, unpublished observation), undiluted supernatant]; (3) three 10 min rinses in wash buffer (450 mм NaCl, 0.3\% Triton X-100, 20 mm sodium phosphate buffer, pH 7.4) and one in PBS (30 min); (4) incubation in sccondary antibody diluted in GSDB for $2 \mathrm{hr}$; (5) three $10 \mathrm{~min}$ rinses in wash buffer and one in PBS ( $30 \mathrm{~min}$ ) followed by a $15 \mathrm{~min}$ rinse in $5 \mathrm{~mm} \mathrm{~PB}, \mathrm{pH} 7.4$. Sections were placed on slides, coverslipped with $90 \%$ glycerol, $10 \%$ PBS, 2.5\% (w/v) 1,4 diazobicyclo[2,2,2] octane (Johnson et al., 1982), and examined with a Zeiss ICM 405 photomicroscope equipped for epifluorescence. Black and white photographs were taken with.Kodak T-Max 400 film. A Sarastro Phoibos 1000 laser confocal microscope system (Sarastro, Inc., Ypsilanti, MI) was used to obtain images of immunostained thick sections. A $40 \times$ oil immersion objective (NA 1.3) was used to obtain confocal sections. For fluorescein imaging, a $488 \mathrm{~nm}$ excitation filter and a $515 \mathrm{~nm}$ barrier filter were used. vaNIS software (Sarastro, Inc., Ypsilanti, MI) was used for reconstruction of serial sections. Photographs were taken directly from the monitor with T-Max 100 film.

For immunoelectron microscopy, the living retina was dissected from the eyecup and chopped $(50-100 \mu \mathrm{m})$ on a Mcllwain tissue chopper. The resultant slices were fixed in a hypotonic solution $(4 \%$ formaldehyde, $0.1 \%$ glutaraldehyde in $5 \mathrm{~mm}$ phosphate buffer, $\mathrm{pH} 7.4$ ) to provide intracellular access of immunogold label (De Camilli et al., 1983). Immunogold labeling for synaptophysin was performed as for immunofluorescence. The polyclonal anti-frog synaptophysin antibody (Valtorta et al., 1988) was diluted 1:50 in GSDB without Triton X-100. Protein A-gold $(5 \mathrm{~nm}$ ) was used at a 1:50 dilution in GSDB (without Triton $\mathrm{X}-100$ ). After labeling, sections were postfixed in $1 \%$ glutaraldehyde in $0.1 \mathrm{M} P B$ for $15 \mathrm{~min}$ and then further postfixed in osmium and potassium ferrocyanide and en bloc stained with uranyl acetate (Townes-Anderson et al., 1985) prior to dehydration and embedding in an Epon mixture. Thin sections, stained with uranyl acetate and lead citrate, were examined in a JEOL $100 \mathrm{CXII}$ electron microscope.

Cell dissociation and maintenance. Dissociation of adult salamander retina was performed as previously described using enzymatic digestion with papain and trituration (MacLeish and Townes-Anderson, 1988). Cell suspensions were plated onto glass coverslips coated with the Sal-1 antibody (MacLeish et al., 1983). In some experiments, substrate antibodies were applied to plastic tissue culture dishes (Falcon). For the plastic dishes, the goat anti-mouse antibody was diluted $1: 10$ in sterile distilled water and allowed to dry on the plastic surface. After rinsing thoroughly with distilled water, Sal-1 hybridoma supernatant was also allowed to dry on the dish surface. After another distilled water rinse, the dishes were allowed to dry and could be stored for a few days at $4^{\circ} \mathrm{C}$. To create a substrate of concanavalin A (ConA), the lectin ( $1 \mathrm{mg} /$ $\mathrm{ml}$; Sigma) was applied to glass coverslips in PBS for 1-3 hr. After a thorough rinse with distilled water, dishes were allowed to dry.
Cells were grown in a medium containing $108 \mathrm{~mm} \mathrm{NaCl}, 3 \mathrm{~mm} \mathrm{KCl}$, 2 mм HEPES, 1 mм NaHCO $, 0.5 \mathrm{~mm} \mathrm{NaH}_{2} \mathrm{PO}_{4}, 1 \mathrm{~mm}$ sodium pyruvate, $0.5 \mathrm{~mm} \mathrm{MgCl}, 16 \mathrm{~mm}_{2}$ glucose, $1.8 \mathrm{mM} \mathrm{CaCl}_{2}, 7 \%$ medium 199 , $1 \times$ minimum essential medium (MEM) vitamin mix, $0.1 \times$ MEM essential amino acids, $0.1 \times \mathrm{MEM}$ nonessential amino acids, $2 \mathrm{~mm}$ glutamine, $2 \mu \mathrm{g} / \mathrm{ml}$ insulin, $2 \mu \mathrm{g} / \mathrm{ml}$ transferrin, $5 \mathrm{mM}$ taurine, $0.8 \mu \mathrm{g} / \mathrm{ml}$ thyroxine, $0.02 \mathrm{~mm}$ phenol red, $10 \mu \mathrm{g} / \mathrm{ml}$ gentamycin, and $1.0 \mathrm{mg} / \mathrm{ml}$ bovine serum albumin. Cells were maintained in a humidified chamber at $10^{\circ} \mathrm{C}$ in air.

For experiments using the microtubule depolymerizing agents colchicine or nocodazole (both obtained from Sigma), drugs were added to culture medium from stock solutions made up in dimethyl sulfoxide (DMSO; $1 \mathrm{mg} / \mathrm{ml}$ and $10 \mathrm{mM}$, respectively). Control cultures received DMSO without drug.

Immunocytochemistry of dissociated cultured cells. For light microscopic immunofluorescence, acutely dissociated or cultured cells were fixed with $4 \%$ formaldehyde in $0.1 \mathrm{M} \mathrm{PB}$ for $1 \mathrm{hr}$ at room temperature or 3-12 hr at $4^{\circ} \mathrm{C}$. For tubulin immunofluorescence, cells were fixed in a microtubule-stabilizing buffer: $100 \mathrm{~mm}$ PIPES, pH 6.9; 5 mM EGTA; $2 \mathrm{mM} \mathrm{MgCl} ; 0.5 \%$ Triton X-100, $4 \%$ formaldehyde; $0.25 \%$ glutaraldehyde. Immunofluorescence labeling was as described above for sections. The synaptophysin and tubulin antibodies were used at a dilution of 1:100; opsin antibody and fuorescein-phalloidin were used at a dilution of 1:25. For double-label experiments, primary antibody and phalloidin were applied simultaneously to cultures. Process length was measured on negatives using JAVA image analysis software (Jandel Scientific, Corte Madeira, CA).

For immunoelectron microscopy, cultured cells were fixed with $4 \%$ formaldehyde, $0.1 \%$ glutaraldehyde in $0.1 \mathrm{M}$ PB for $1 \mathrm{hr}$ at room temperature or $3-12 \mathrm{hr}$ at $4^{\circ} \mathrm{C}$. $4 \mathrm{D} 2$ immunogold labeling was performed as described above for sections, omitting Triton X-100. Gold-conjugated goat anti-mouse $\operatorname{IgG}(5 \mathrm{~nm})$ was used for the secondary antibody. Following immunolabeling, cells were fixed in $1 \%$ glutaraldehyde in 0.1 $M$ PB for $15 \mathrm{~min}$ and prepared for electron microscopy as described above.

Cationic ferritin uptake. Cells maintained in culture for $7 \mathrm{~d}$ were rinsed once with salamander salt solution containing $50 \mathrm{~mm} \mathrm{KCl} \mathrm{(NaCl}$ concentration reduced to $61 \mathrm{~mm}$ to adjust osmolarity) and $1.8 \mathrm{~mm} \mathrm{CaCl}_{2}$. Cationic ferritin (Cooper Biomedical) was added in the same salt solution at a concentration of $0.25 \mathrm{mg} / \mathrm{ml}$. Cells were maintained in the presence of ferritin for 10 or $60 \mathrm{~min}$ at $10^{\circ} \mathrm{C}$ in a dark incubator. Control dishes contained $2 \mathrm{mM} \mathrm{CoCl}_{2}$ and no added $\mathrm{CaCl}_{2}$. After aspiration of the ferritin-containing solution, cells were fixed and prepared for electron microscopy as described above. Some sections were examined unstained to facilitate detection of ferritin particles.

\section{Results}

\section{Immunocytochemistry in the intact retina}

Synaptic vesicle proteins. We first localized synaptic vesicle proteins (SVPs) in the intact retina to determine whether SVP immunostaining accurately revealed the shape of the photoreceptor presynaptic terminals. Observations on presynaptic terminals in situ werc subscquently compared to those in vitro. In the salamander retina, rod somata extend one or more thin connecting fibers, or axons, each of which terminates in a large synaptic vesicle-filled expansion within the outer plexiform (synaptic) layer (OPL). Radiating from the base of the rod terminal are one or more fine basal processes, extending laterally up to $20 \mu \mathrm{m}$, which form small synaptic vesicle-filled varicosities along their length. Salamander cone cells, whose somata are positioned closer to the OPL, do not possess an axon-like process but form a broad synaptic vesicle-filled cytoplasmic extension in the OPL. As for the rod cells, cone terminals give rise to basal processes. Both rod and cone terminals (both large terminals and smaller basal process varicosities) form multiple ribbon synapses at sites of contact with postsynaptic processes (Custer, 1973; Lasansky, 1973; Townes-Anderson et al., 1985; Mariani, 1986).

Antibodics against SV2 and synaptophysin, both intcgral membrane proteins of small synaptic vesicles, were used as 

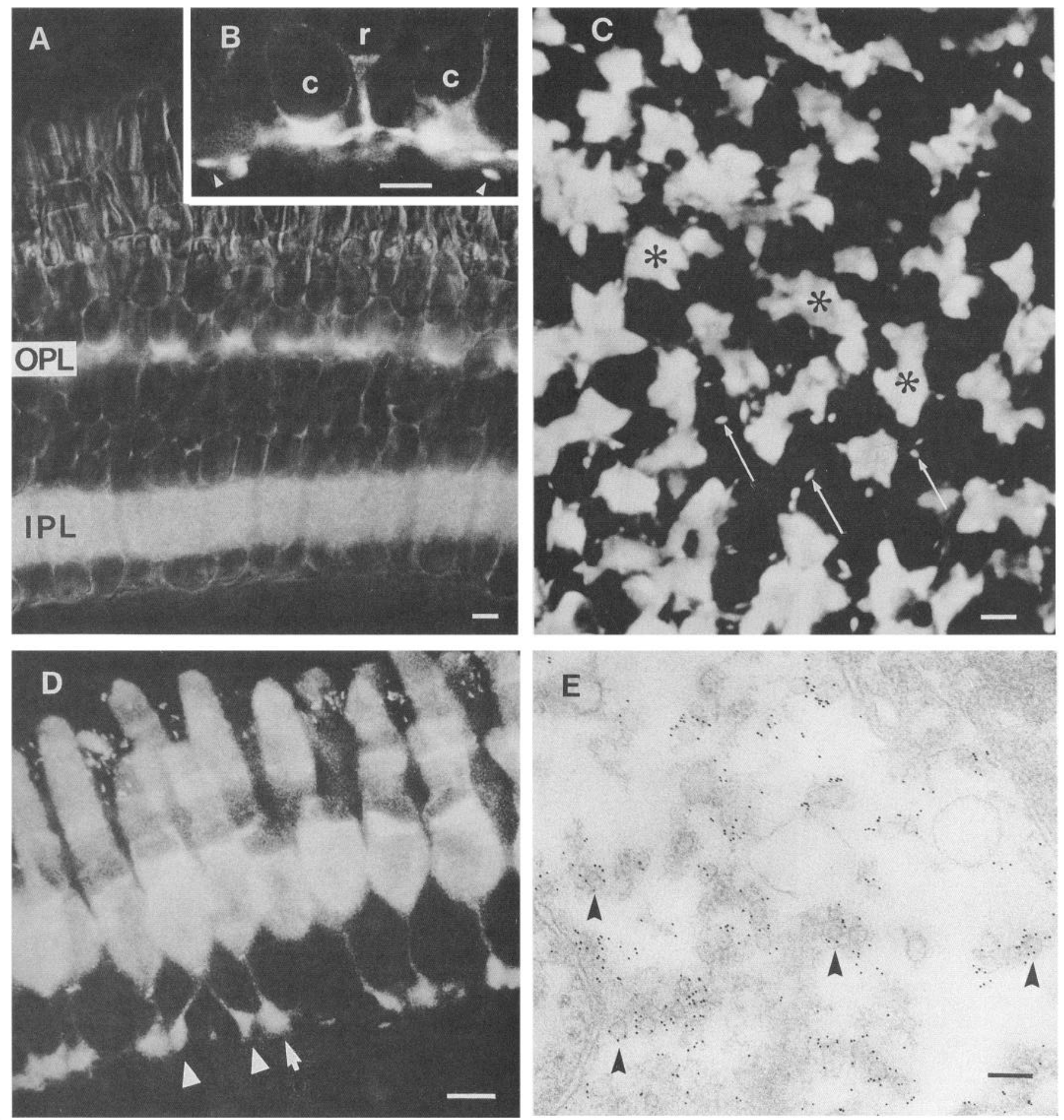

Figure 1. Immunocytochemical visualization of photoreceptor synaptic terminals in salamander retina. $A$, Immunofluorescence localization of the synaptic vesicle protein SV2 in salamander retina. A combined phase-contrast/immunofluorescence micrograph shows strong immunoreactivity in large photoreceptor terminals in the outer plexiform layer $(O P L)$ as well as a band of more granular labeling in the inner plexiform layer (IPL). $B$, Higher-power view of SV2 immunofluorescence in rod $(r)$ and cone $(c)$ receptor terminals. This image was obtained by combining serial confocal sections comprising a $5 \mu \mathrm{m}$ thickness. Note the broad cone synaptic endings contiguous with cone somata and the smaller rod terminal. Smaller immunostained varicosities are also present (arrowheads). C, Horizontal view of SV2-immunostained terminals in a flat-mounted retina, reconstructed from serial confocal sections. Large rod and cone terminals are clustered in small islands $\left(^{*}\right)$; smaller varicosities are evident in the intervening zones (arrows). These probably represent small synaptic endings of rod and cone basal processes. $D$, Visualization of rod photoreceptor terminals with an independent marker, a rod-specific monoclonal antibody. Rod cells extend one (arrow) or two (arrowheads) axon-like connecting fibers with terminal expansions. $E$, Immunoelectron microscopy of synaptophysin in a photoreceptor terminal. Immunolabeling within the terminal is due primarily to labeling of synaptic vesicles: colloidal gold particles decorate small clear vesicles (arrowheads) but not other intracellular membranes. Scale bars: $A-D, 10 \mu \mathrm{m} ; E, 0.1 \mu \mathrm{m}$. 

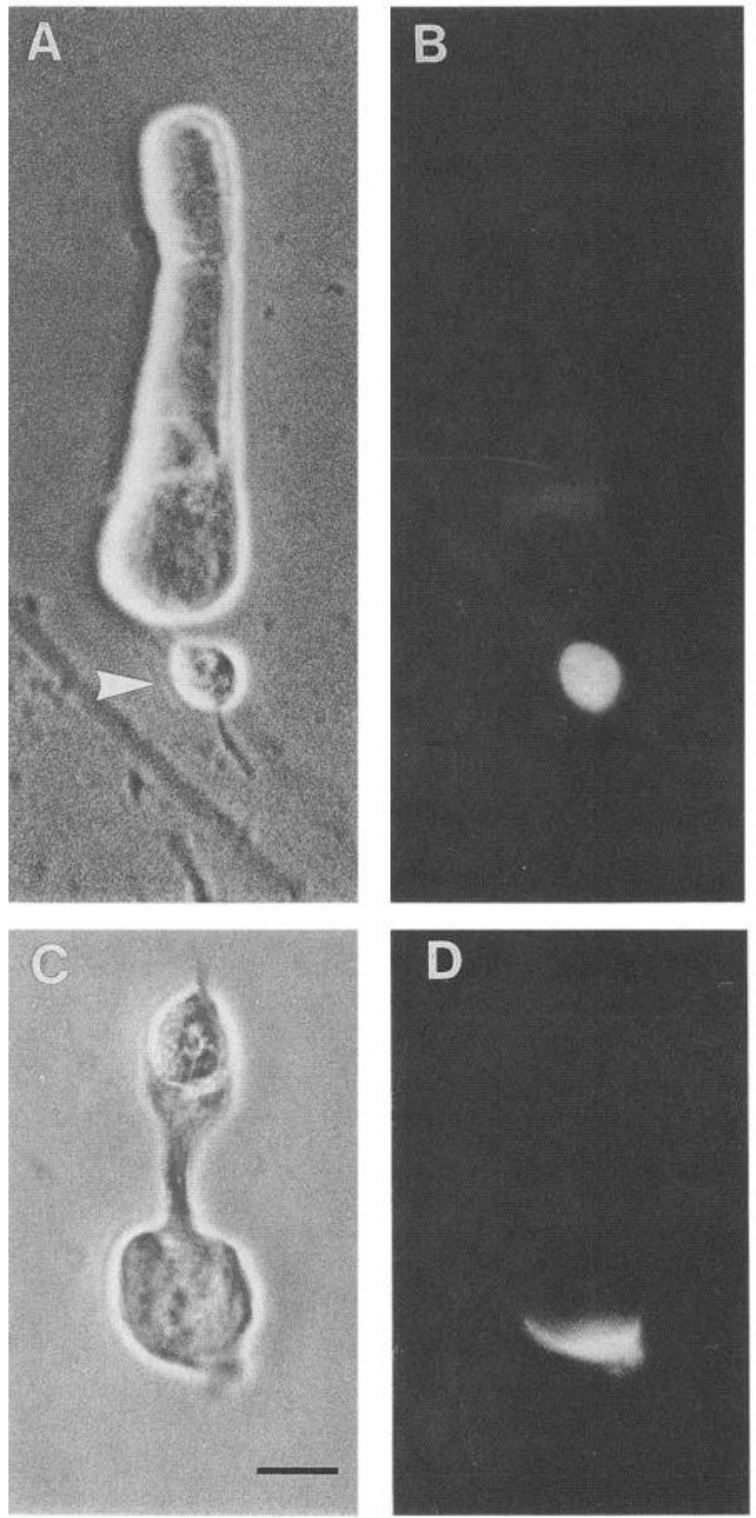

Figure 2. Immunofluorescence localization of SV2 in acutely isolated photoreceptor neurons. $A$, Phase-contrast micrograph of an intact, acutely isolated rod cell. $B$, Bright SV2 immunostaining is concentrated in the large spherical synaptic ending (arrowhead in $A$ ). Barely detectable immunostaining is present in the soma. $C$, Phase-contrast image of an isolated cone cell that has lost its outer segment. $D$, Intense SV2 immunostaining is present in a broad, crescent-shaped zone at the base of the soma. The rest of the cytoplasm is essentially devoid of staining. Scale bar, $10 \mu \mathrm{m}$.

markers for presynaptic terminals (Buckley and Kelly, 1985; Valtorta et al., 1988). These antibodies are expected to stain those regions of presynaptic structures that contain dense accumulations of synaptic vesicles. The synaptic terminals of rod and cone photoreceptors contain numerous synaptic vesicles not only at their active zones, but throughout the entire presynaptic terminal. Thus, SVP immunocytochemistry should allow visualization of entire synaptic endings. In all experiments, immunostaining patterns for both SV2 and synaptophysin were identical.

Bright SVP immunofluorescence was seen in large photoreceptor endings in the OPL (Fig. 1A). Confocal microscopy clearly revealed the broad synaptic endings of cone cells and the more compact, spherical rod cell synaptic terminals (Fig. 1B). A rod-specific antibody against an unidentified cytoplasmic antigen allowed selective visualization of rod terminals: rod somata extended one or two axons, $12-16 \mu \mathrm{m}$ in length, which gave rise to 4-6- $\mu$ m-diameter terminals (Fig. $1 D$ ). Cone terminals, viewed by SVP immunostaining, appeared to be broad $(6-10 \mu \mathrm{m})$ extensions of the basal cytoplasm (Fig. 1A,B). In addition to large rod and cone synaptic endings, smaller (1-3 $\mu \mathrm{m}$ diameter) terminals were labeled near the vitreal border of the OPL (Fig. 1B). Their size, shape, and position were consistent with previous descriptions of varicosities formed by basal processes (Custer, 1973; Lasansky, 1973; Mariani, 1986). These small synaptic varicosities were also visible in horizontal confocal sections through the OPL (Fig. 1C). Additionally, this perspective revealed that large rod and cone terminals were not randomly positioned but were clustered in small islands. The intervening zones were devoid of large terminals but contained the small varicosities.

To confirm that the immunostaining we observed by light microscopy was due to the immunolabeling of synaptic vesicles, we performed immunoelectron microscopy (Fig. $1 E$ ). Immunogold labeling for synaptophysin was concentrated around small clear vesicles within photoreceptor terminals. Other membranes were unlabeled.

Rod-specific opsin. The rod-specific anti-opsin monoclonal antibody 4D2, which recognizes an extracellular (or intradiscal) opsin epitope, was used to identify rod photoreceptors in vitro. In the intact salamander retina, intense immunolabeling was present along the outer segments of all rod photoreceptors. Cone cells were completely unlabeled (not shown). A previous study in the frog retina showed that this antibody labeled most $(>96 \%)$ but not all rod cells (Hicks and Molday, 1986). The unlabeled cells were thought to be green rod cells, which comprise a small subpopulation of rod cells. The fact that we saw no unlabeled rod cells out of more than 300 examined suggests that green rod cells in the salamander are a very small $(<1 \%)$ subpopulation, in agreement with a morphological analysis of salamander rod subtypes (Mariani, 1986).

\section{Photoreceptors in vitro}

SVP localization immediately following isolation. After dissociation, rod photoreceptors were present either completely intact (Fig. $2 A$ ) or in three states of partial preservation: (1) lacking only a synaptic terminal, (2) lacking only an outer segment, or

Figure 3. Process outgrowth and synaptic-like varicosity formation in vitro. A, Twelve hours after plating, cultured photoreceptors have extended a few short, filopodial processes (arrows). B. After $36 \mathrm{hr}$, the rod cell on the left has grown more filopodia, mostly emanating from the intact outer segment. The photoreceptor on the right, probably a rod cell that lost its outer segment, has two distinct types of process outgrowth: radially oriented filopodia and a thick, branched neuritic process (arrow). C, Phase-contrast micrograph of a photoreceptor at $7 \mathrm{~d}$ in culture. Thicker neuritic processes often form ovoid varicosities along their length (arrowheads). Varicosities, whose length and width varied from 2 to 15 and 1 to $6 \mu \mathrm{m}$, respectively, often give rise to filopodia at their distal ends. $D$, SV2 immunostaining of the photoreceptor in $C$. All varicosities show intense SV2 immunostaining. No other structures demonstrated such uniformly bright immunostaining. Less intense immunostaining is present in a discrete perinuclear region, consistent with localization of the Golgi apparatus (arrowhead). E, Synaptophysin immunofluorescence in rod and cone cells identified by the 

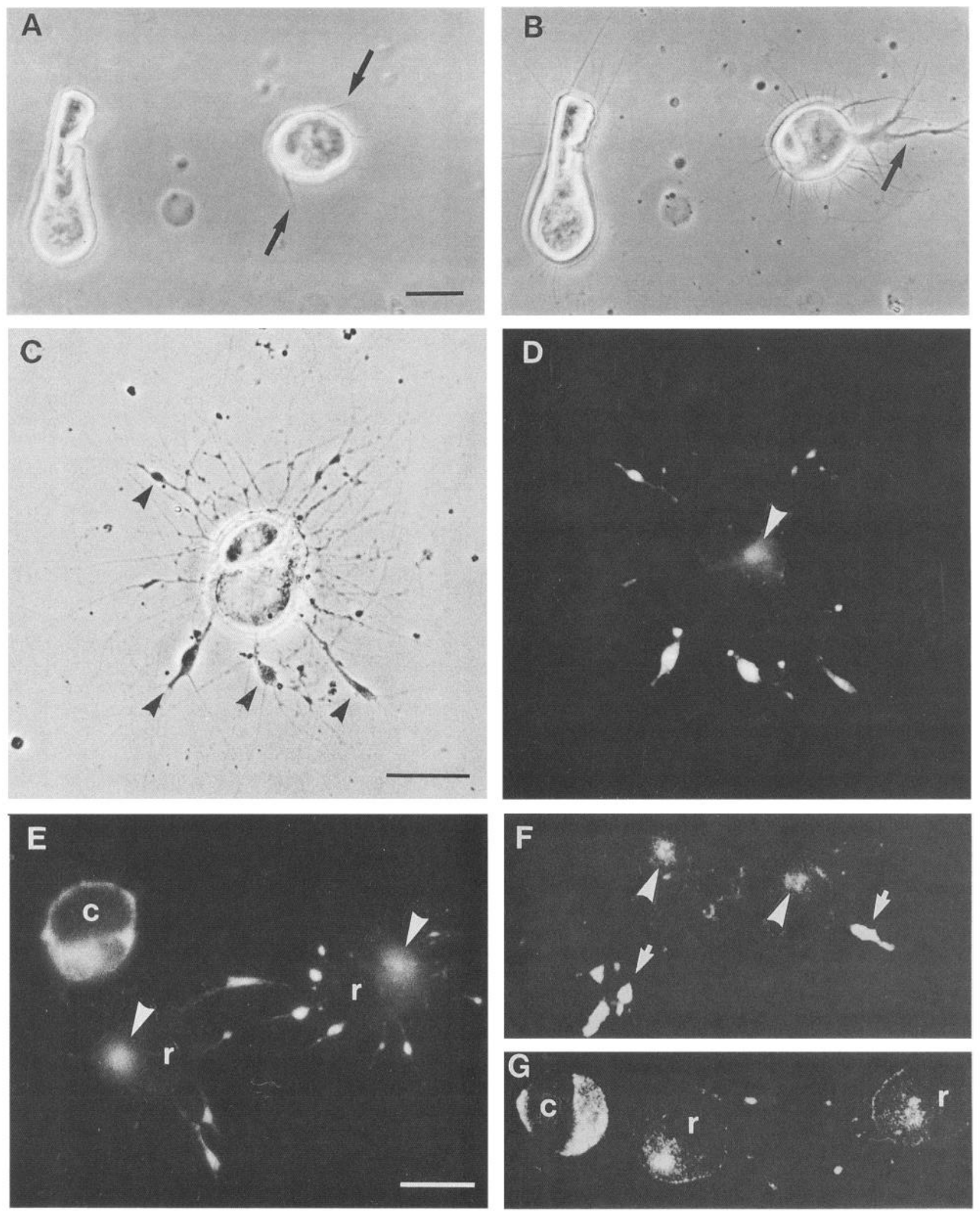

presence or absence of the rod-specific opsin antibody 4D2. A cone cell $(c)$ has failed to generate any synaptic vesicle-containing varicosities and has a high level of soma SVP immunostaining, suggesting an accumulation of synaptic vesicles or precursors in the cell body cytoplasm. In contrast, two rod cells $(r)$ have formed numerous synaptophysin-immunoreactive varicosities and have low levels of cell body immunostaining except in a perinuclear region (arrowheads). F, The optical sectioning capability of the confocal microscope demonstrates that intense synaptophysin immunofluorescence in varicosities is a result of a higher intensity of immunostaining and not merely due to increased thickness in these structures (arrows). Less intense immunoreactivity is also present in a perinuclear region (arrowheads). $G$, Confocal microscopy of cell body synaptophysin immunostaining in identified rod and cone cells. Again, bright synaptophysin immunofluorescence is seen in a cone cell $(c)$, whereas rod cells $(r)$ have low levels of soma synaptophysin except for the perinuclear region. Scale bars, $20 \mu \mathrm{m}$. 


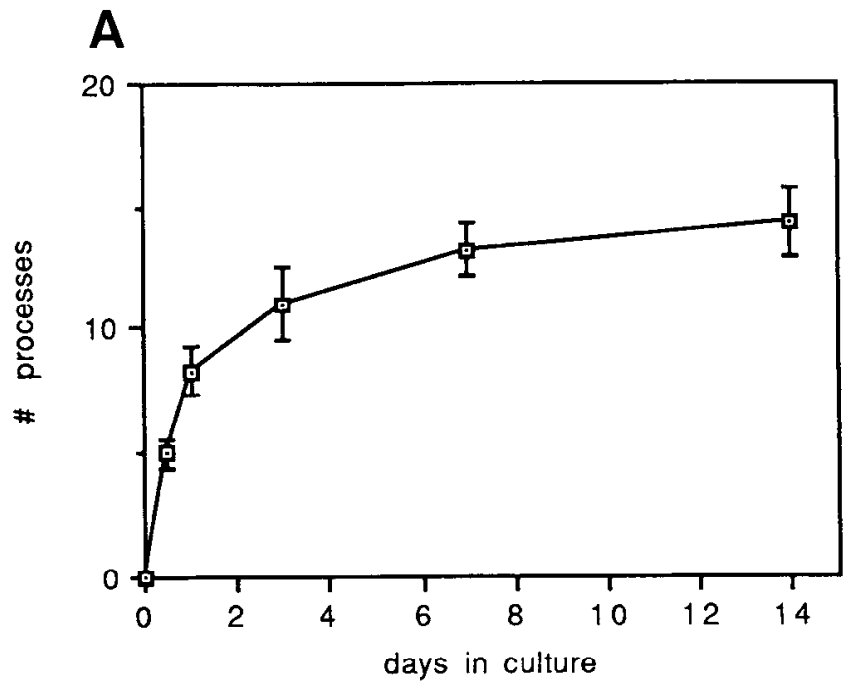

B

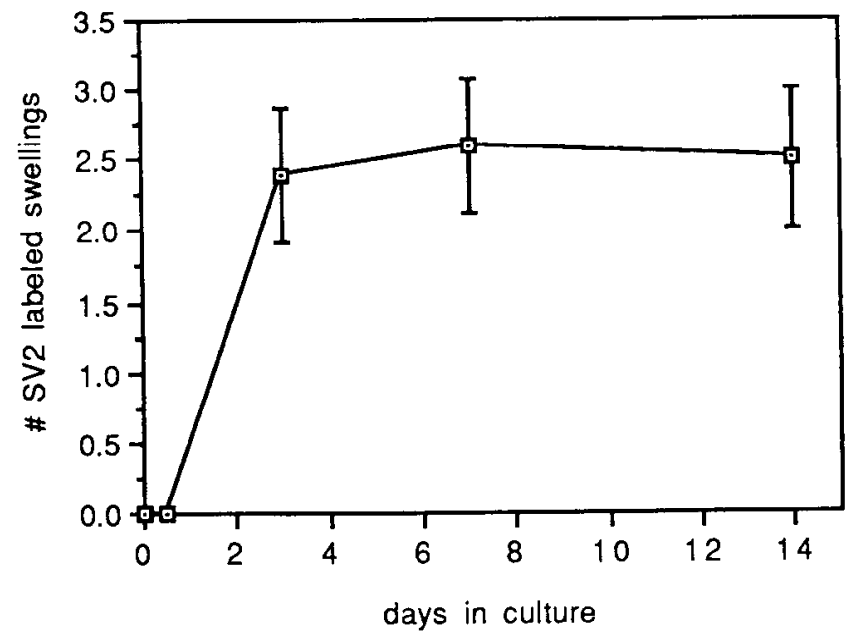

Figure 4. Time course of process outgrowth and synaptic varicosity formation. $A$, The number of primary processes extended per cell was determined by phase-contrast microscopy. Points represent the mean \pm SEM. $B$, The number of SV2-immunostained varicosities per cell was determined in the same set of cultures as $A$. Points are mean \pm SEM.

(3) lacking both a synaptic terminal and an outer segment. Photoreceptors without outer segments could be easily identified under phase-contrast microscopy by the presence of an ellipsoid hody, the large, dense accumulation of mitochondria between the nucleus and the base of the outer segment. Intense SVP immunostaining was present in the terminal and axon, and low but detectable immunoreactivity in perinuclear regions of the soma (Fig. 2B). Rod cells lacking a morphologically identifiable terminal contained only dim perinuclear staining.

Cone photoreceptors, although they rarely retained an intact outer segment, could be identified by their elongated inner segment (Fig. 2C). All cone cells exhibited bright SVP immunostaining in a broad crescent at the basal side of the nucleus, indicating that most of the synaptic ending was retained after dissociation (Fig. 2D). Dim perinuclear and inner segment staining was also observed.

Process outgrowth and varicosity formation. Immediately following plating, photoreceptors, identified by the presence of an ellipsoid body, comprised $45-60 \%$ of all cells. Approximately
$55 \%$ of photoreceptors were rod cells (4D2 positive) and $45 \%$ were cone cells (4D2 negative). Similar rod: cone ratios were reported in the intact salamander retina (Laurens and Williams, 1917; Attwell et al., 1984; Mariani, 1986). Examination of cultured cells at $12 \mathrm{hr}$ and $7 \mathrm{~d}$ revealed no significant changes in total photoreceptor number or in the ratio of rod to cone cells. Therefore, it is unlikely that expression of rod opsin was induced in non-rod cells in vitro. Furthermore, mitotic figures were never observed in cultured photoreceptors. Thus, it is unlikely that there was significant photoreceptor genesis or cell death in these cultures.

During the first day after plating, photoreceptors began to extend short, filopodial processes (Fig. $3 A$ ). After a few days in culture, photoreceptors exhibited two distinct types of process outgrowth: (1) fine, straight, or curved, radially oriented processes ranging from 5 to $80 \mu \mathrm{m}$ in length, and (2) thicker neuritic processes, ranging from 5 to $20 \mu \mathrm{m}$ in length (Fig. $3 B$ ). Filopodia had only occasional branches; neurites were more highly branched. Neuritic processes were less numerous than filopodia and often contained ovoid varicosities along their length. Varicosities, whose length and width varied from 2 to 15 and 1 to $6 \mu \mathrm{m}$, respectively, usually gave rise to a number of filopodia at their distal ends.

All varicosities formed by photoreceptors in culture showed intense SVP immunostaining (Fig. $3 C, D$ ). No other structures demonstrated such uniformly bright immunostaining. For this reason, we will refer to them as synaptic varicosities. Filopodial processes as well as nuclei and ellipsoid bodies in all cells lacked SV2 or synaplophysin immunostaining. The optical sectioning capability of the confocal microscope demonstrated that the intense SVP immunofluorescence in varicosities was a result of a higher density of immunostaining and not merely due to increased thickness in these structures (Fig. $3 F$ ).

The level of soma SVP immunostaining was high in some cells and low in others (Fig. 3E,G). In general, photoreceptors lacking varicosities had the highest levels of soma immunofluorescence, suggesting an accumulation of synaptic vesicles or precursors in the cell body cytoplasm. In contrast, cells that formed multiple varicosities had low levels of cell body SVP immunostaining, except for a discrete zone of SVP immunoreactivity consistently seen between the nucleus and ellipsoid body by both conventional (Fig. $3 D, E$ ) and confocal (Fig. $3 F, G$ ) microscopy. This region probably corresponds to the location of the Golgi apparatus, where synaptic vesicle membrane biogenesis, and thus accumulation of SVPs, may occur (TixierVidal et al., 1988; Janetzko et al., 1989; Schmied and Holtzman, 1989). This was supported by double-labeling experiments showing colocalization of SV2 or synaptophysin immunoreactivity and binding of WGA, a Golgi marker, in the perinuclear region (data not shown).

The initial retention of an intact synaptic terminal did not qualitatively affect subsequent growth and varicosity formation. Rod cells initially isolated with or without a synaptic terminal were capable of filopodial and ncuritic proccss outgrowth and synaptic-like varicosity formation. Likewise, the initial retention of the outer segment by rod cells did not qualitatively affect processes growth and varicosity formation. However, rod cells (and occasionally, cone cells) that retained intact outer segments generally grew fewer neuritic processes and formed fewer synaptic-like varicosities. Furthermore, these cells often grew long filopodia from their distal outer segments with fewer filopodia radiating from the soma (Fig. 3B). 

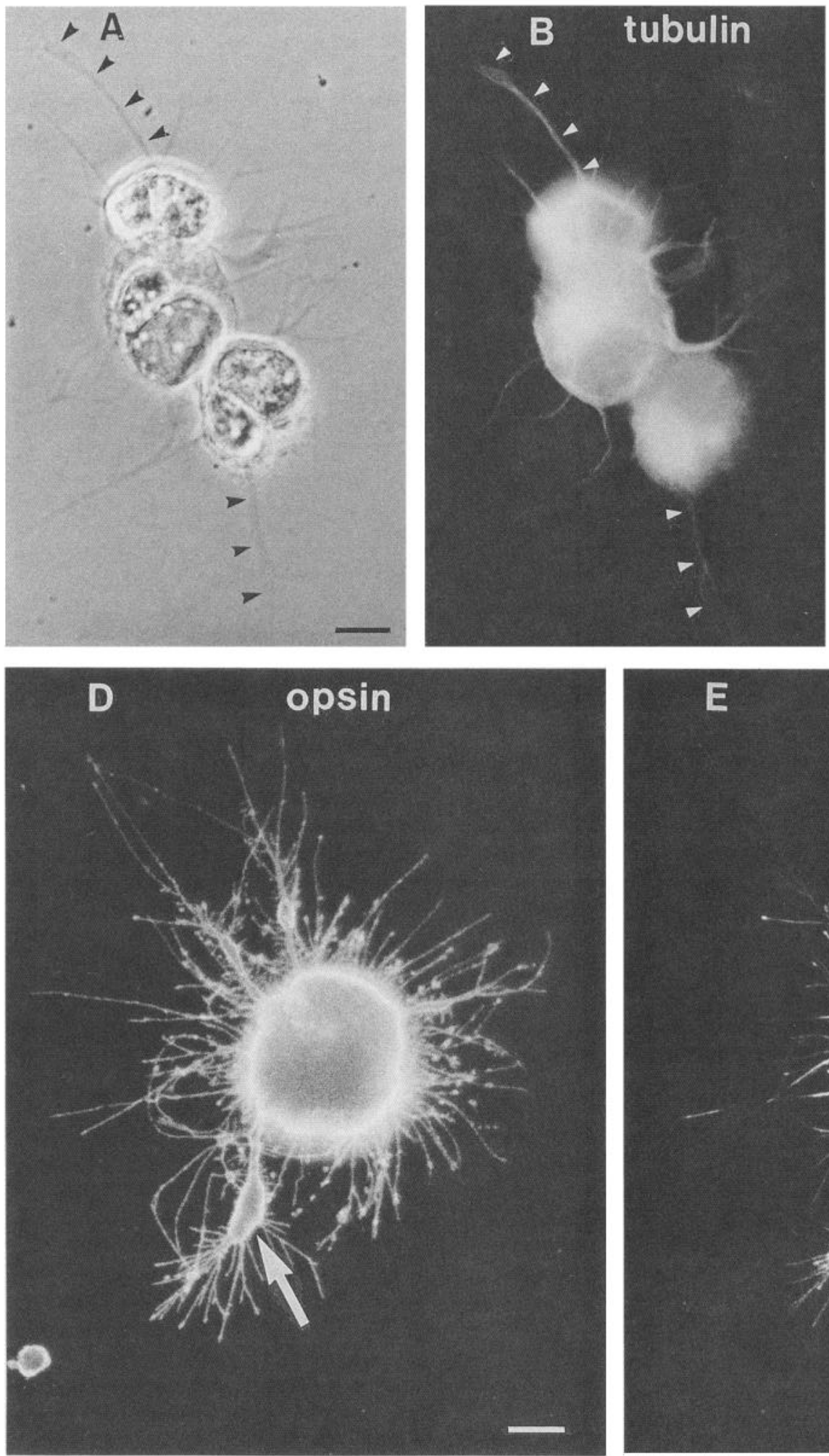

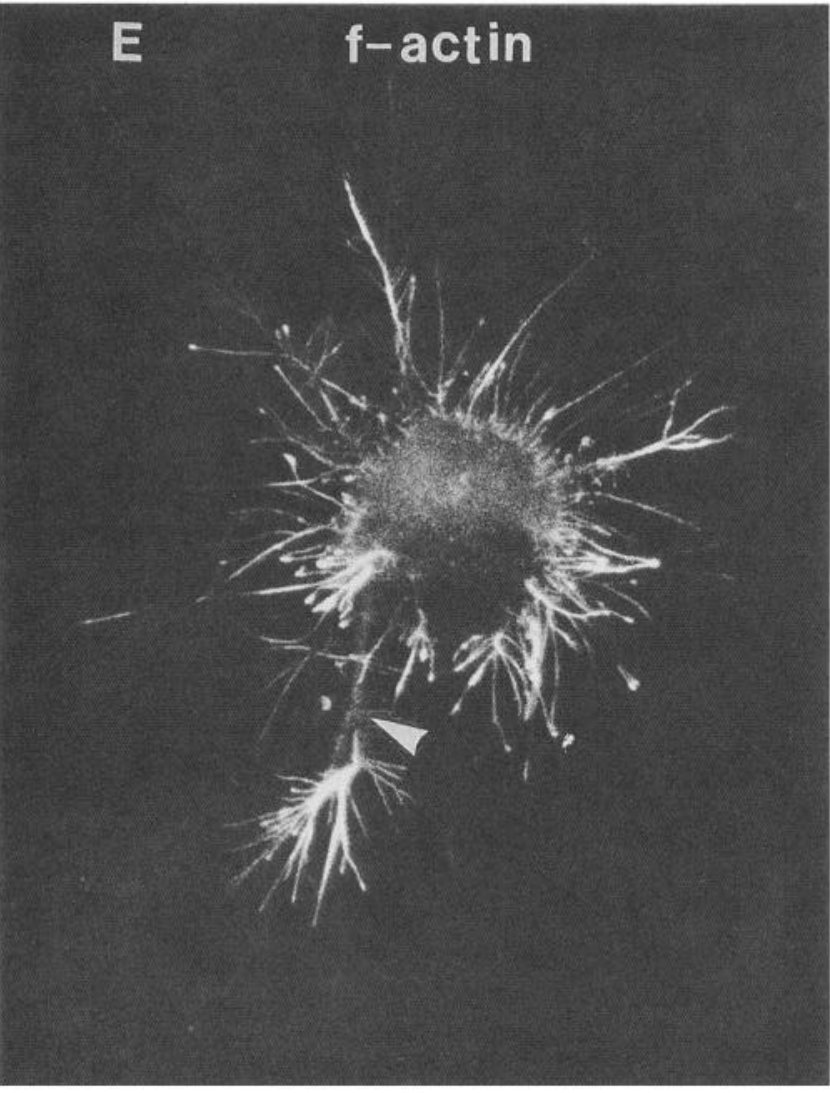

Figure 5. Cytoskeletal composition of photoreceptor processes. $A-C$, Photoreceptors cultured for $7 \mathrm{~d}$. $A$, Phase-contrast micrograph showing numerous filopodia and thicker neuritic processes (arrowheads). The cells were double labeled for tubulin $(B)$ and filamentous actin $(C)$. Tubulin immunostaining is seen in cell bodies and in a few neuritic processes (arrowheads, B). F-Actin, visualized with fluorescein phalloidin, is present in filopodia radiating from the soma, but absent from neuritic processes (arrowheads, $C$ ). $D$ and $E$, Double-label immunostaining of a $3 \mathrm{~d}$ culture for rod-specific opsin and actin. All processes and a varicosity (arrow, D) show bright plasma membrane opsin immunostaining. All opsinimmunoreactive filopodia contain $\mathrm{f}$-actin. Note, however, that the varicosity (arrowhead, $E$ ) is relatively devoid of $\mathrm{f}$-actin. Scale bars: $A$, $10 \mu \mathrm{m}$; $D, 5 \mu \mathrm{m}$. 
Time course of process outgrowth and synaptic varicosity formation. The number of primary processes greater than $5 \mu \mathrm{m}$ in length and visible by phase-contrast microscopy was determined at $12 \mathrm{hr}$, and $1,3,7$, and $14 \mathrm{~d}$. The number of processes per cell increased rapidly during the first $3 \mathrm{~d}$ in culture and approached a maximum by $7 \mathrm{~d}$ (Fig. $4 A$ ).

The number of SV2-immunoreactive varicosities formed by photoreceptors was also determined in the same set of experiments. For quantitation, varicosities were defined as SV2-immunostained structures located at least $5 \mu \mathrm{m}$ from the soma whose smallest diameter was at least $2 \mu \mathrm{m}$. The number of SV2immunolabeled varicosities per cell increased rapidly from zero at $12 \mathrm{hr}$ to $2.4 \pm 0.5$ at $3 \mathrm{~d}$ (Fig. $4 B$ ). No significant increase in varicosity number was seen between 3 and $14 \mathrm{~d}$ in culture. Thus, the most rapid increase in the number of processes and synaptic varicosities took place in the first $3 \mathrm{~d}$ of culture.

Cytoskeletal composition of process outgrowt hand varicosities. Because process outgrowth by cultured photoreceptors seemed to take two basic morphologies, we sought to determine whether these distinct forms of growth might be associated with different cytoskeletal compositions. Double-labeling was performed using phalloidin, a marker for filamentuus actin (f-actin), and an antibody to tubulin (Fig. $5 A-C$ ). Bright phalloidin staining was present throughout all filopodial processes, whereas neuritic processes had very low levels of f-actin staining. Immunolocalization of tubulin was more restricted than f-actin. In addition to bright cell body immunofluorescence, prominent immunostaining was seen only in the neuritic processes and the varicosities associated with them. In 4D2-positive rod cells, opsin immunoreactivity occurred along both the cell body plasma membrane as well as along the membranc of all ncwly formed processes; opsin staining, therefore, could be used to highlight process outgrowth. Double staining for opsin and phalloidin revealed that all rod filopodia contained f-actin; staining was present both in the processes emanating from the cell soma as well as those arising from the distal ends of varicosities (Fig. $5 D, E$ ).

Ultrastructural characterization of process outgrowth. Electron microscopy confirmed and extended the light microscopic observations (Fig. 6). Filopodia contained a fine, filamentous network without any obvious microtubules and sparse, heterogeneous membranous vesicles (Fig. $6 B$ ). Neuritic processes, on the other hand, had microtubules coursing down their length as well as a fine filamentous mesh (Fig. $6 \mathrm{C}$ ). Small clear vesicles $(50-80 \mathrm{~nm})$ were seen in neuritic processes, often associated with microtubules (Fig. $6 D$ ).

Examination of varicosities at high power revealed them to be densely packed with $50-80 \mathrm{~nm}$ small clcar vesicles, whosc size and homogeneity suggest that they are identical to synaptic vesicles (Fig. $6 E$ ). Varicosities also contained a few dense-core vesicles along with microtubules and finer filaments. Sections taken perpendicular to the substrate plane showed the varicosities to range from 1 to $3 \mu \mathrm{m}$ in depth.
Vesicle-covered ribbons were occasionally seen in synaptic vesicle-filled varicosities. More commonly, however, ribbons appeared in photoreceptor somata. Their origin is unknown; such ribbons may have been present initially in synaptic endings retained after isolation, or they could be newly synthesized.

\section{Functional assessment of synaptic varicosities}

Neurotransmitter release via exocytosis is normally followed by a compensatory endocytotic recycling of vesicle membrane (Heuser and Reese, 1973). Endocytotic vesicles can be labeled with an extracellular tracer, thus providing indirect evidence for vesicular neurotransmitter release. We applied an electron-dense extracellular tracer, cationic ferritin, in the presence of a depolarizing stimulus, $50 \mathrm{~mm} \mathrm{KCl}$. After a $10 \mathrm{~min}$ incubation, many ferritin-containing, invaginating coated pits and vesicles (an early stage of endocytosis) were observed (Fig. 7A). At 10 and $60 \mathrm{~min}$, ferritin-containing vesicles consistent with small synaptic vesicles were observed in varicosities (Fig. $7 B, C$ ). The proportion of vesicles containing tracer was less (maximum of $9 \%$ ) than that previously reported in the intact retina or in acutely isolated rod photoreceptors (Schacher et al., 1974; Ripps et al., 1976; Schaeffer and Raviola, 1978; Townes-Anderson et al., 1985). At $60 \mathrm{~min}$, uptake of ferritin was also seen in somata, mostly in vesicles associated with synaptic ribbons. It is possible that labeled vesicles in somata were originally endocytosed in the varicosities and retrogradely transported. Conversely, some of the ferritin-containing vesicles seen in varicosities might have been endocytosed in the cell body and anterogradely transported. However, the presence of labeled coated pits, coated vesicles, and small vesicles in varicosities indicates that some recycling occurred locally. Moreover, a recent study of rat brain has shown that virtually all neuronal clathrin-coated vesicles contain synaptic vesicle components, further suggesting that the label-containing coated vesicles observed here are involved in synaptic vesicle membrane recycling (Maycox et al., 1992). Control dishes, which contained $50 \mathrm{~mm}$ potassium chloride and 2 mM $\mathrm{CoCl}_{2}$, without added $\mathrm{Ca}^{2+}$, showed very few ferritin-containing vesicles.

\section{Differences in synaptic varicosity formation between rod cells and cone cells}

Double-labeling experiments using the opsin antibody to label rod cells and anti-synaptophysin to mark synaptic varicosities allowed a quantitative comparison of varicosity formation by rod and cone cells (Fig. 8). Rod photoreceptors formed on average $1.6 \pm 0.14$ varicosities (mean \pm SEM; range, $0-9 ; n=$ 179 cells), whereas one cells formed only $0.30 \pm 0.06$ varicosities (range, $0-3 ; n=101$ cells). Thus, the formation of multiple synaptic varicosities was largely a trait of rod photoreceptors. It should be noted, however, that $40 \%$ of rod cells and more than $75 \%$ of cone cells did not form synaptic varicosities in the $7 \mathrm{~d}$ culture period. The lack of varicosity formation by the

\footnotetext{
Figure 6. Electron microscopy of cultured rod photoreceptors. A, Both filopodial (arrowheads) and thicker neuritic processes (arrows) extend from a rod cell soma. One neurite has formed a small varicosity (v). The cell was identified by immunogold labeling using a rod-specific opsin primary antibody $(5 \mathrm{~nm}$ gold particles are visible at higher magnification in $B, C$, and $E$ ). $B$, Filopodia are essentially devoid of membranous organelles and contain filamentous material but no microtubules. $C$, Neuritic processes contain microtubules and membranous organelles, including small $(50-80 \mathrm{~nm})$ vesicles. $D$, A high-power electron micrograph of a neurite shows small vesicles aligned along a microtubule. Short filaments connect some vesicles to the microtubule (arrowheads). $E$, A rod cell varicosity is filled with small (50-80 nm) clear vesicles as well as some larger densecore vesicles (arrowheads). Microtubules extend from the neurite into the varicosity (arrows, upper right). Scale bars: $A, 1 \mu \mathrm{m} ; B, C$, and $E, 0.5$ $\mu \mathrm{m} ; D, 0.1 \mu \mathrm{m}$.
} 


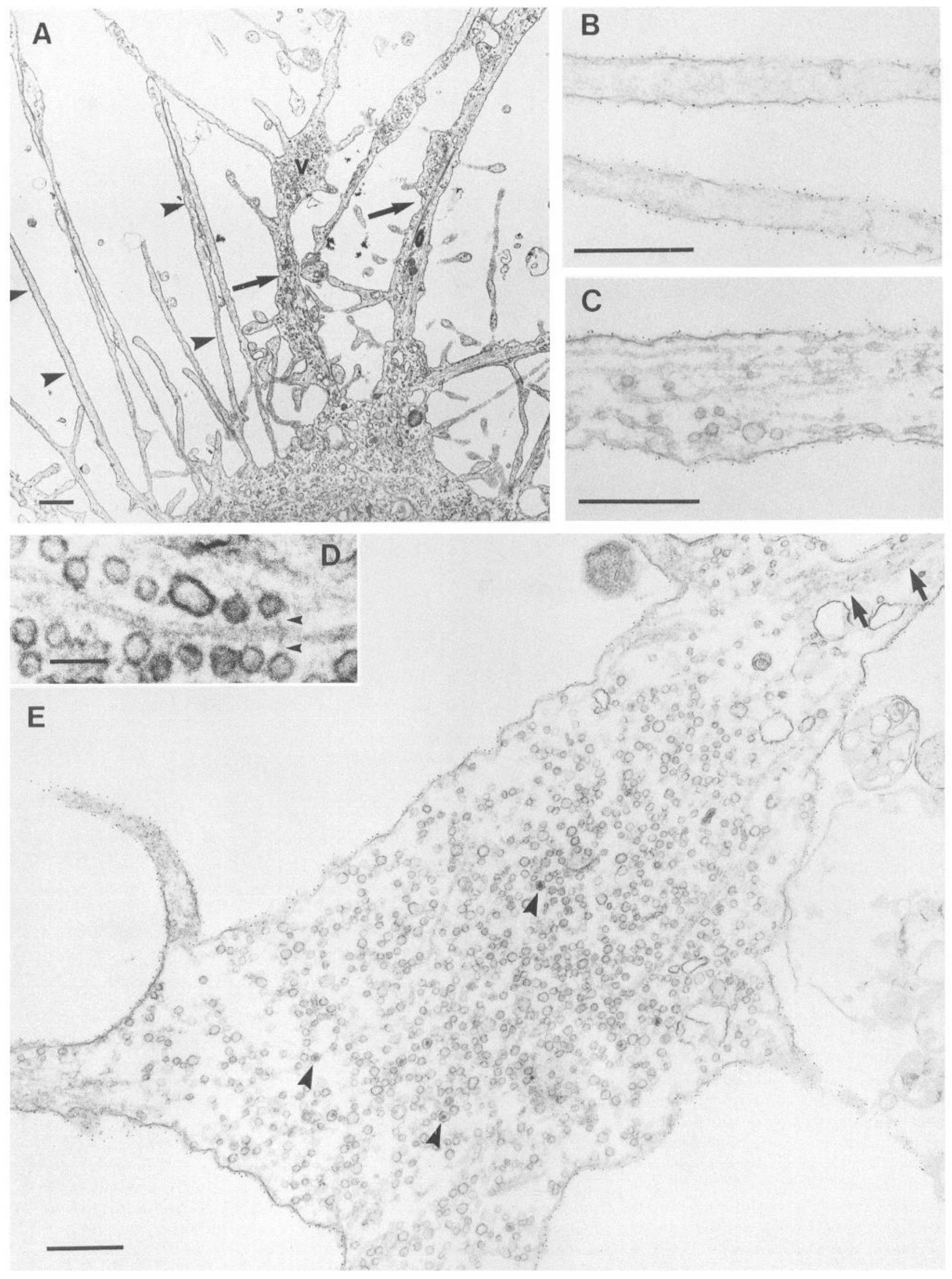



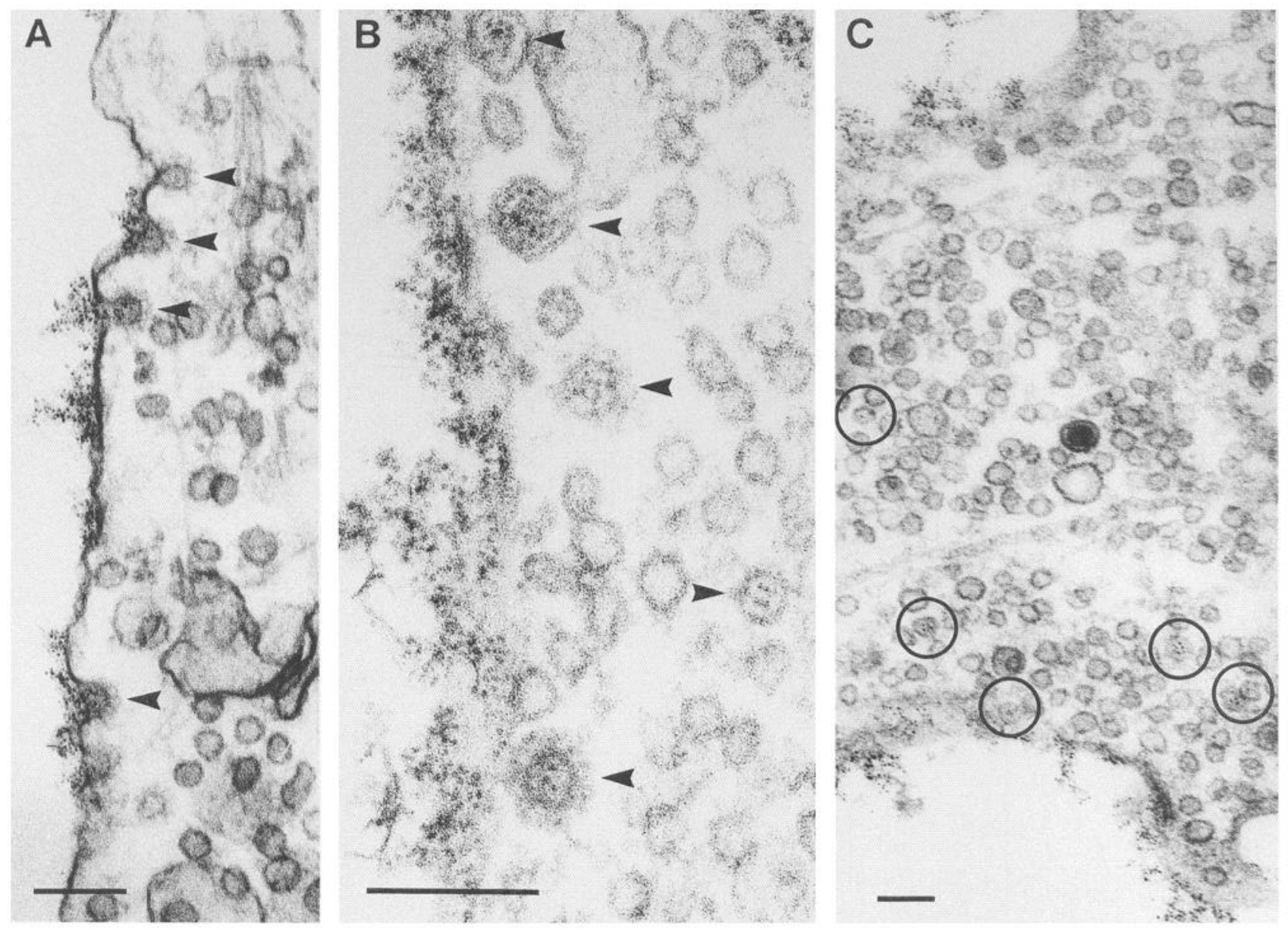

Figure 7. Assessment of depolarization-induced synaptic vesicle membrane recycling in regenerated photoreceptor synaptic varicosities. Photoreceptors cultured for $7 \mathrm{~d}$ were exposed to $50 \mathrm{~mm} \mathrm{~K}+$ in the presence of extracellular cationic ferritin $(0.25 \mathrm{mg} / \mathrm{ml})$. A, After $10 \mathrm{~min}$, numerous coated pits containing cationic ferritin are present along the plasma membrane of a varicosity (arrowheads). $B$ and $C$, After 60 min, coated and uncoated vesicles within varicosities contain ferritin particles (arrowheads, B; circles, C). Scale bars, $0.1 \mu \mathrm{m}$.

majority of cone cells in culture may reflect the in situ morphology of the cone terminal, which extends directly from the cell soma rather than from an axonal process. In fact, the structures counted as cone varicosities were more accurately described as broad lamellopodia than discrete varicosities.

As previously noted (Fig. $3 E, G$ ), the level of soma SVP staining was inversely correlated with the number of regenerated synaptic varicosities when examined among all photoreceptors. Use of the rod-specific opsin antibody revealed that rod cells (4D2-positive) cultured for 3-7 d usually exhibited low levels of cell body SVP immunostaining but intense SVP immunofluorescence in multiple, distinct varicosities. Cone cells (4D2negative cells), on the other hand, usually contained high levels of SVP immunoreactivity in the cell body cytoplasm and only occasionally in one or two varicosities.

Using anti-opsin and colloidal gold secondary antibodies, rod and cone cells could be distinguished in thin sections. Electron microscopic examination of 4D2-positive rod cells (Fig. 6) and 4D2-negative cone cells (not shown) showed that filopodia and varicosities from both cell types were similar in fine structure. Cell bodies of cone cells, however, differed from rod cells in that they usually contained a noticeably higher density of small clear vesicles, consistent with the higher levels of SVP immunostaining seen in cone somata.

\section{Factors influencing process outgrowth and synaptic varicosity} formation

Disruption of synaptic varicosity formation by microtubule depolymerizing agents. Since the synaptic vesicle-filled varicosities seemed to be exclusively associated with microtubule-containing neuritic processes, we sought to determine whether the presence of intact microtubules was necessary for the formation of varicosities. The continuous presence of either colchicine (1 $\mu \mathrm{g} / \mathrm{ml})$ or nocodazole $(1 \mu \mathrm{M})$ completely blocked the formation of SVP-immunoreactive varicosities and microtubule-containing neuritic processes in cells maintained for $7 \mathrm{~d}$ in culture (Fig. $9 A-F)$. Cells treated with either drug exhibited markedly increased levels of soma SVP immunostaining, suggesting an accumulation of synaptic vesicles or their precursors in the cell body cytoplasm. The specificity of the blocking effect was supported by the finding that these agents did not prevent the growth of numerous f-actin-containing and opsin-immunoreactive filopodial processes (Fig. 9G,H). An additional finding was that filopodia extended in the presence of nocodazole or colchicine, unlike those in control cultures, were completely unbranched. A dose-response curve indicated that the minimum effective colchicine concentration necessary to block SVP-immunoreactive varicosity formation completely was between 0.1 and 1.0 
$\mu \mathrm{g} / \mathrm{ml}$ (Fig. 10). The blocking effect of nocodazole was shown to be partially reversible by treating cells with $1 \mu \mathrm{M}$ nocodazole for $3 \mathrm{~d}$ (a period during which control cultures formed numerous varicosities); subsequently, the nocodazole was removed and the cells were maintained in normal medium for $4 \mathrm{~d}$. A proportion of cells were able to extend short neuritic processes with SVP-immunoreactive varicosities during the recovery period.

Growth and synaptic varicosity formation in the absence of cell contact and on alternative substrates. Although most experiments were performed at a relatively low cell density (100400 cells $/ \mathrm{mm}^{2}$ ), many cells were nonetheless able to form one or more cell contacts. To determine whether the presence of other cells was necessary for process outgrowth and/or synaptic varicosity formation, photoreceptors were cultured for $7 \mathrm{~d}$ at very low density (1-10 cells/well). Labeling of the cultures with the opsin antibody to visualize processes and varicosities demonstrated that rod photoreceptors exhibited qualitatively similar patterns of process outgrowth and varicosity formation at very low cell densities and even when maintained in single cell cultures (not shown). Thus, neither cell contact nor exogenously derived cellular factors were necessary to induce the observed pattern of growth and synaptic varicosity formation.

The substrate used in all experiments was the monoclonal antibody Sal-1. To determine whether growth and varicosity formation were dependent on a specific interaction with Sal-1, other substrates were tested. Previous attempts to grow adult photoreceptors on polylysine, laminin, or fibronectin were unsuccessful; cells attached poorly if at all and failed to extend processes (MacLeish et al., 1983). Two substrates did allow photoreceptor attachment: the lectin ConA, which has been successfully used for the growth of dorsal root ganglion ncurons and adult leech and Aplysia neurons in vitro (DeGeorge et al., 1985; Chiquet and Acklin, 1986; Lin and Levitan, 1987), and untreated tissue culture plastic. Growth and varicosity formation qualitatively similar to that seen on Sal-1 was observed on both substrates (not shown). The number of adherent cells and the amount of outgrowth, however, were much less on tissue cullure plastic than on either Sal-1 or ConA.

\section{Discussion}

Our results indicate that adult photoreceptor neurons can regenerate new processes and form presynaptic-like structures when maintained in vitro. The sequence of events leading to synaptic varicosity formation is depicted schematically for a rod photoreceptor that has lost both outer segment and synaptic terminal (Fig. 11). Within $12 \mathrm{hr}$ of plating, the cell rounded up and extended radially oriented filopodia, rich in filamentous actin. In addition, synaptic vesicles, or their precursors, began to accumulate in the soma. By $3 \mathrm{~d}$, thicker neuritic processes, distinguished by the presence of numerous microtubules and synaptic vesicle-filled varicosities, were apparent. The transport of synaptic vesicles to forming varicosities occurred presumably along microtubules, since varicosity formation was abolished by microtubule depolymerizing agents. A depletion of synaptic vesicles was observed in the soma, concomitant with their transport to nascent synaptic varicosities. The size and number of the regenerated varicosities and the length of the neurites on which they formed were similar to those observed in situ, suggesting the existence of endogenous limitations on growth and synaptic regeneration.

Process outgrowth and varicosity formation by photoreceptors appeared to occur autonomously; they were not dependent
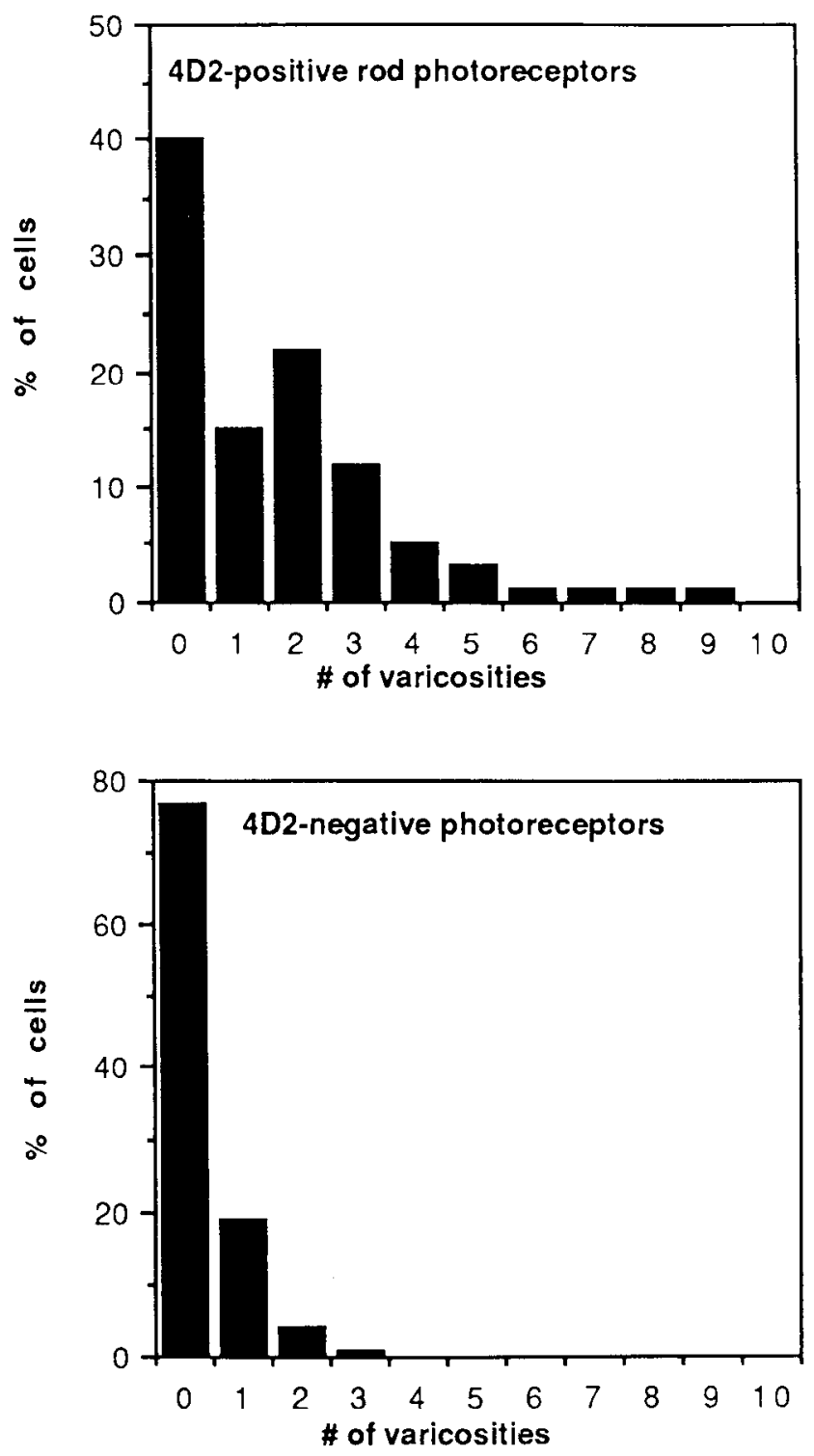

Figure 8. Quantitative difference in synaptic varicosity formation bctween rod and cone cells. Top, Rod cells (4D2-positive) contained from 0 to 9 synaptophysin-immunoreactive varicosities $(1.6 \pm 0.14$ per cell; mean $\pm \mathrm{SEM} ; n=179$ cells). Bottom, Cone cells (4D2-negative photoreceptors), in contrast, formed 0-3 synaptophysin-immunoreactive varicosities $(0.30 \pm 0.06 ; n=101$ cells $)$.

on cell contact or soluble cell-derived factors, nor were they dependent on a specific cell-substrate interaction. The structural reorganization observed in culture may reflect either (1) normal cytoskeletal dynamics and membrane flow within photoreceptor cells after the removal of inhibitory constraints (e.g., cell-cell contact, cell-substrate adhesion, and/or diffusible factors), or (2) a specific response to cellular injury incurred upon dissociation from the intact retina.

\section{Comparison to previous in vitro studies of developing photoreceptors}

Other in vitro studies of photoreceptors have utilized cells from embryonic or early postnatal retinas. None of these studies specifically examined the development of synaptic terminals. However, they suggest differences in growth properties between developing and adult photoreceptors. Cone cells from chick retina 

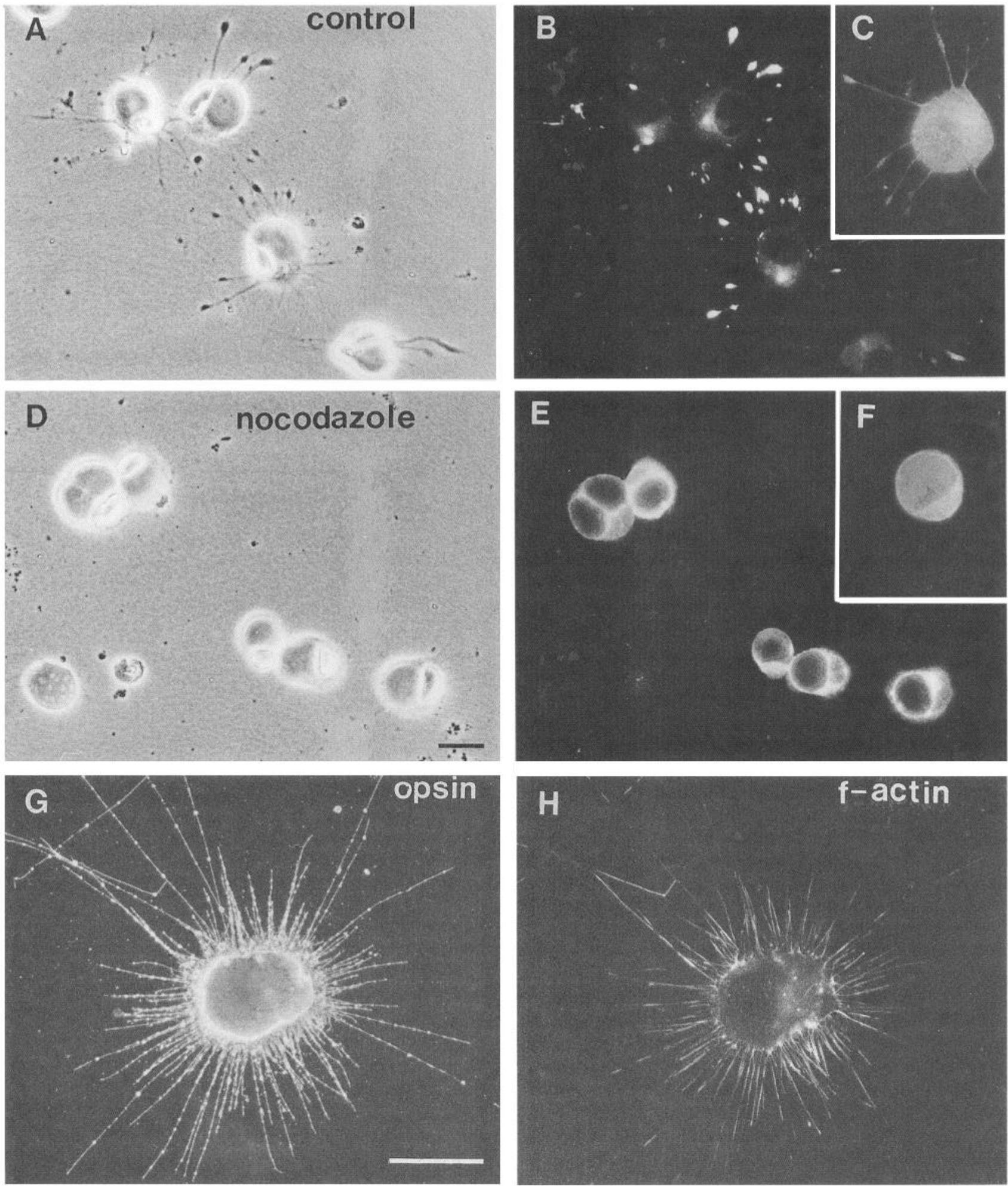

Figure 9. Disruption of synaptic varicosity formation but not filopodial extension by the microtubule depolymerizing agent nocodazole. $A-C$, Control culture at $7 \mathrm{~d}$. Photoreceptors have radial processes and varicosities, as seen in phase contrast $(A)$; all varicosities are SV2 immunoreactive $(B)$. Tubulin immunostaining is present in soma and neuritic processes $(C)$. $D-F$, Nocodazole $(1 \mu \mathrm{M})$-treated culture at $7 \mathrm{~d}$. Some fine radial filopodia are visible by phase contrast $(D)$. SV2 immunostaining shows a complete absence of varicosities. Intense SV2 staining is present only in photoreceptor cell bodies $(E)$. Tubulin immunostaining is present only in soma; no microtubule-containing neurites are present $(F)$. $G$ and $H$, Processes extended in the presence of nocodazole contain opsin and f-actin. Opsin immunofluorescence is seen in the plasma membrane of the soma and radial filopodia. Note that the filopodia are straight and unbranched $(G)$. F-actin is present in filopodia $(H)$. Identical results were seen in cells treated with colchicine $(1 \mu \mathrm{g} / \mathrm{ml})$. Scale bars, $20 \mu \mathrm{m}$. 


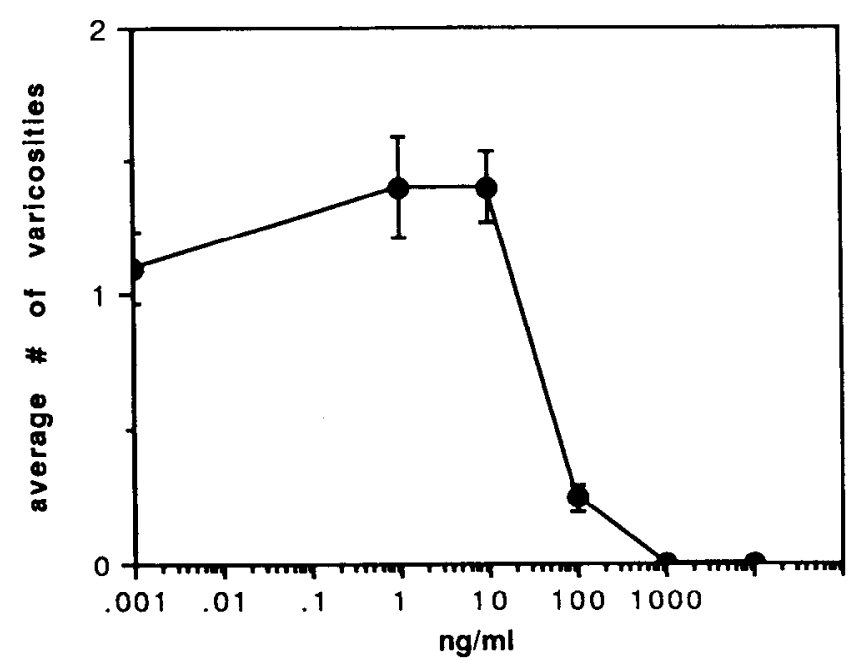

Figure 10. Dose-response curve demonstrating colchicine effect on synaptic varicosity formation. The number of SV2-immunoreactive varicosities per cell (mean \pm SEM) after $7 \mathrm{~d}$ in culture decreased with increasing doses of colchicine, with the minimal effective concentration between 0.1 and $1 \mu \mathrm{g} / \mathrm{ml}$. were shown to develop an elongated morphology and polarized opsin distribution on a polyornithine substrate in the absence of cell contacts (Adler et al., 1984). These cells usually extended a single ncuritc from their basal pole and an opsin-containing process from their apical pole. Postnatal rat rod photoreceptors extended neuritic processes on the surface of retinal glial cells (Akagawa and Barnstable, 1986; Araki et al., 1987; Hicks and Courtois, 1988; Kljavin and Reh, 1991). Like salamander rod cells (but unlike chick), cultured rat rod cells failed to establish a polarized opsin distribution (i.e., plasma membrane of all processes and soma contained opsin; Hicks and Courtois, 1988). Developing rat rod cells, however, did not extend straight, radially oriented filopodial processes, which we observed in salamander cells. Formation of synaptic varicosities by cultured mammalian photoreceptors has not been directly addressed. Apart from possible species differences, the variations in process outgrowth between mature and developing photoreceptors suggest that the in vitro behavior of mature photoreceptors is not merely a recapitulation of developmental processes.

\section{Resemblance of varicosities formed in vitro to presynaptic terminals in situ}

Structural, functional, and molecular criteria indicate that the varicosities formed by cultured photoreceptors resemble pre-

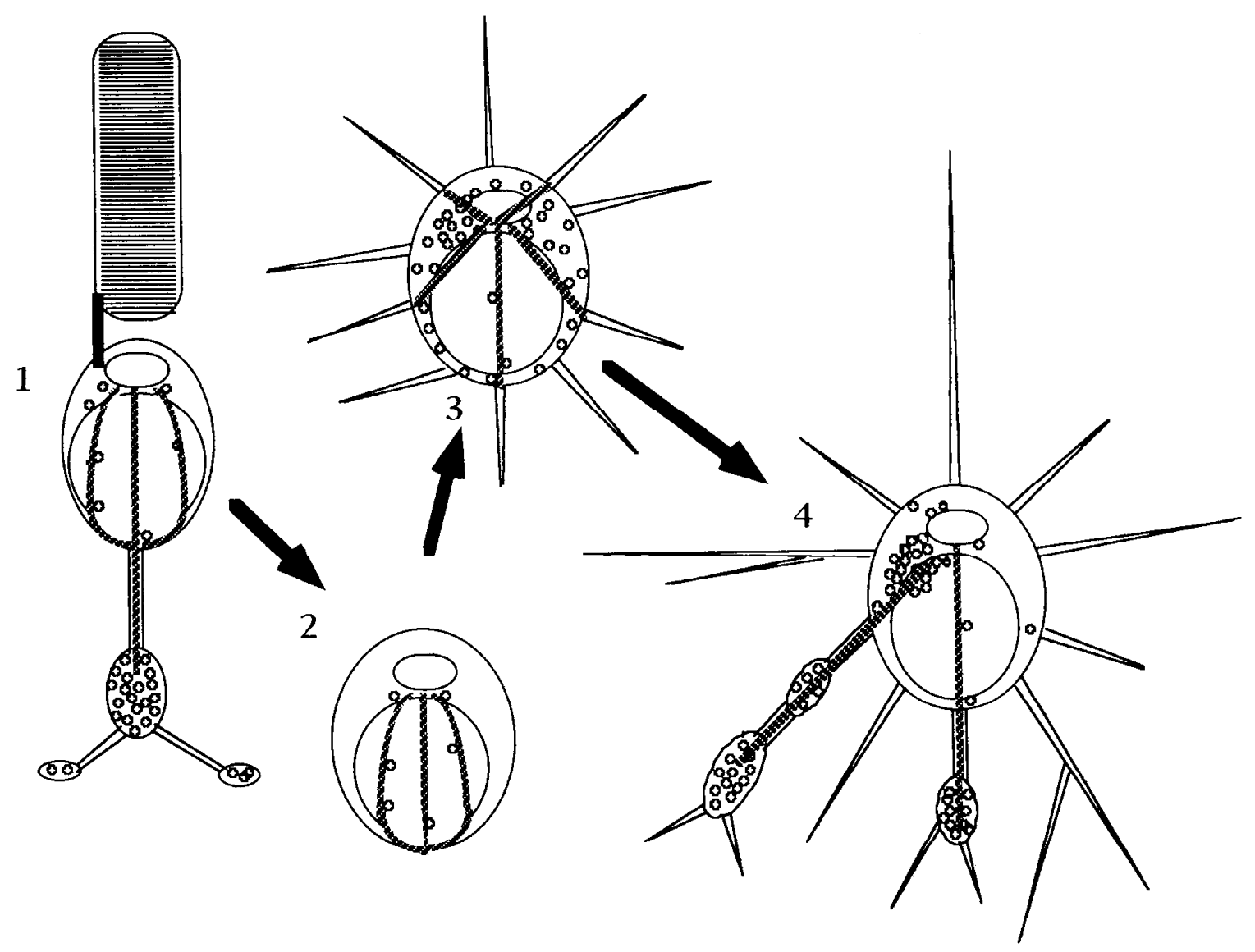

Figure 11. Schematic summary of rod cell process growth and synaptic varicosity formation in vitro. 1 , Rod photoreceptor in the intact retina. Microtubules (dark, stippled lines), originating in a perinuclear zone, extend into the synaptic terminal. Synaptic vesicles (or precursors) are presumably transported along microtubules to the terminal, where they accumulate. 2, Dissociation of the retina results in photoreceptors in a variety of morphological states. Illustrated here is a rod cell that has lost its outer segment, synaptic terminal, and connecting fiber. 3, After 1-2 d in culture. The cell extends numerous, radially oriented filopodia. Synaptic vesicles (or precursors) accumulate in the cell body. 4, After 3-14 d in culture. Thicker neuritic processes appear, which contain microtubules. Vesicles are transported along microtubules, and accumulate in en passant and terminal varicosities. Consequently, the soma contains relativcly fewcr synaptic vesicles, except for those vesicles (or precursors) in the perinuclear region. 
synaptic terminals of photoreceptors in vivo. Varicosities were of a size comparable to terminals and varicosities in situ. Like terminals in situ, they contained abundant small, clear vesicles and immunoreactivity for the synaptic vesicle proteins SV2 and synaptophysin. Finally, varicosities, like synaptic terminals within the intact retina, displayed stimulus-induced labeling of vesicles.

The differences observed between synaptic regeneration by rod cells and cone cells in vitro, resemble, to a first approximation, structural differences between their synaptic terminals in situ. Rod cells extended neuritic processes and formed multiple synaptic vesicle-filled varicosities. Cone cells, on the other hand, usually did not form discrete varicosities and tended to accumulate synaptic vesicles and SVP immunostaining in somata. In situ, rod cells form one or more discrete synaptic terminals at a distance from the soma whereas the cone synaptic terminal is a broad cytoplasmic extension. The diminished formation of varicosities observed in cone cells may be due to endogenous differences in regenerative capacities of rod and cone cells. Evidence of a molecular basis for such endogenous differences includes the finding that frog cone cells, but not rod cells, contain abundant acetylated tubulin in inner segment microtubules (Sale et al., 1988). This posttranslational modification is associated with microtubule stabilization. In addition, rat photoreceptors (mainly rod cells), but not avian photoreceptors (mainly cone cells), contain MAP2c, a neuronal microtubule-associated protein typically found in embryonic tissue (Tucker and Matus, 1988; Tucker et al., 1988). Alternatively, differences in the plasticity of presynaptic structures may be related to synaptic injury. For instance, the retention of the original presynaptic terminal by essentially all cones but only a portion of rod cells raises the possibility that the original axon suppresses subsequent regeneration of new varicosities by cone cells, or that removal of the axon is necessary to stimulate regenerative growth. In rod cells, however, we have observed that retention of the axon did not prevent neurite and varicosity formation.

Our demonstration of depolarization-induced vesicle labeling in regenerated varicosities indicates that the varicosities are capable of synaptic vesicle recycling and suggests that they release neurotransmitter by synaptic vesicle exocytosis. A recent study using an immunocytochemical approach demonstrated that growing axons of developing hippocampal neurons, prior to synapse formation, can also undergo exo/endocytotic synaptic vesicle membrane recycling, although the activity appeared to be spontaneous (Matteoli et al., 1992). Electrophysiological techniques have been used to demonstrate directly the ability of growth cones in culture to release transmitter, both spontaneously and evoked, in the absence of postsynaptic contact (Hume et al., 1983; Young and Poo, 1983). Direct proof of the functional capability of regenerated terminals in our system will require a method, such as the membrane patch detection technique (Hume et al., 1983; Young and Poo, 1983), to measure locally the release of transmitter from a varicosity. It is important to note, however, that the varicosities we observed differ from growth cones in that they do not appear to move along the substrate. Furthermore, they contain dense accumulations of homogeneous synaptic vesicles, unlike growth cones. Photoreceptor varicosities are perhaps more closely related to the vesicle-filled varicosities formed by cultured sympathetic neurons, which have also been shown to be capable of depolarization-induced vesicle labeling (Buckley and Landis, 1983).
The relatively low level of vesicular recycling we observed in varicosities may be due to a low rate of neurotransmitter release in the absence of a differentiated presynaptic active zone, which in the photoreceptor is a membrane-anchored, electron-dense plate, covered with synaptic vesicles, and referred to as the ribbon. Although we observed that the initial steps in photoreceptor presynaptic differentiation proceeded in the absence of postsynaptic contact, later steps may well require postsynaptic cues. Future experiments should allow the identification of postsynaptic signals that induce the focal accumulation of presynaptic active zone components, including the ribbon and $\mathrm{Ca}^{2+}$ channels.

Unlike the synaptic terminals in situ, varicosities formed in culture contain abundant opsin in their plasma membranes (see, e.g., Fig. 5D). We hypothesize that this is due, in part, to the redistribution of opsin from the outer segment; this redistribution in turn is a result of the breakdown of a diffusion barrier present in adult rod cells in situ. Consistent with this idea, we have observed that the redistribution of opsin from rod outer segment to synaptic terminal takes place within minutes after retinal dissociation (J. W. Mandell and E. Townes-Anderson, unpublished observations). Such a rapid redistribution is not surprising given the high mobility of opsin within the membrane (Poo and Cone, 1974). A similar redistribution of opsin from outer segment to inner segment following dissociation was reported in frog and rat rod photoreceptors (Spencer et al., 1988; Hicks et al., 1989). In addition, in culture newly synthesized opsin may distribute throughout the rod cell plasmalemma; cultured postnatal rat rod cells were shown to contain opsin immunoreactivity throughout the soma and processes (Akagawa and Barnstable, 1986; Araki et al., 1987). Rod cells in the normal developing retina, in fact, express opsin in both cell body and processes (Hicks and Barnstable, 1987). Even in normal adult rod cells in situ, opsin has been reported along the plasmalemma of the inner segment and cell body (Fekete and Barnstable, 1983; Hicks and Barnstable, 1987). Thus, rather than attribute the presence of opsin in the plasma membrane of regenerated varicosities to misexpression and mistargeting, we would suggest that the adult membrane barrier(s) preventing opsin diffusion into the synaptic terminal is not present in isolated rod cells. The presence of opsin in synaptic membranes might provide an experimental test of vesicle recycling specificity, that is, whether the vesicle retrieval mechanism is able to exclude opsin (not a normal constituent of synaptic vesicles) while retaining SVPs and lipids.

\section{Vesicle targeting and microtubules}

Synaptic vesicle-filled varicosities were selectively associated with microtubule-containing neurites. Furthermore, microtubule depolymerizing agents completely blocked neurite formation and the accumulation of synaptic vesicles in varicosities, but did not diminish actin-rich and opsin-containing filopodial outgrowth. The fact that synaptic vesicle-filled varicosities never appeared along actin-containing processes indicates that presynaptic varicosity formation is selectively associated with the presence of intact microtubules. These observations are reminiscent of studies of a neuroendocrine cell line, AtT-20. These mouse pituitary tumor cells accumulate dense-core secretory granules in the tips of processes extended in culture (Kelly et al., 1983). Disruption of microtubules completely blocked the accumulation of secretory vesicles, but did not prevent insertion of the viral glycoprotein $\mathrm{G}$ into the cell body plasma membrane 
(Rivas and Moore, 1989). The authors suggested that regulated secretory vesicles are targeted to process tips by specific interactions with microtubules, whereas constitutive secretory proteins are targeted to the plasmalemma by some other mechanism. A possible analogy to the constitutive, microtubule-independent pathway in photoreceptors is the continual addition of opsincontaining membrane. Support for this idea is the finding that intact microtubules are not needed for rod outer segment membrane assembly (Vaughan et al., 1989). Similarly, our demonstration that opsin-containing filopodia are extended in the presence of microtubule depolymerizing agents is consistent with this hypothesis.

\section{Structural plasticity of photoreceptor presynaptic terminals}

A large body of work indicates that a variety of mature neurons are capable of replacement and remodeling of synapses (for reviews, see Cotman and Nieto-Sampedro, 1984; Greenough and Bailey, 1988; Steward, 1989; Aguayo et al., 1990). The present study indicates that mature rod and cone photoreceptors can regenerate new presynaptic terminals in culture. Synaptic growth by mature rod photoreceptors in vivo has been demonstrated as well. In experimental models of retinal degeneration, surviving rod cells were shown to respond with an increase in the total perimeter of synaptic terminals and in the number of synaptic ribbons per terminal (Jansen and Sanyal, 1984, 1987; Sanyal et al., 1992). The authors suggested that terminals of the surviving rod cells receive a stimulus for growth from the deafferented postsynaptic bipolar cells. In our in vitro system, however, no such stimulus is necessary for synaptic growth. Thus, there is evidence, both in vitro and in vivo, for plasticity of photoreceptor synaptic terminals.

The stimuli responsible for the induction of terminal regeneration in photoreceptor cells remain to be identified. We have demonstrated that the induction is not dependent on cell contact or cell-derived soluble factors, nor is the response dependent on contact with a specific substrate. Possible stimuli for regeneration include (1) removal of cell contact-mediated constraints on synaptic growth, (2) loss of diffusible inhibitory factors, and (3) growth of synaptic terminals in response to cellular injury. We cannot, however, rule out the possible contribution of autocrine mechanisms in the regenerative process. Our observation that some growth occurs even in virtually undamaged rod cells suggests that significant cell injury is not necessary to induce a growth response. Thus, the removal of normal contact-mediated or soluble inhibitory factors may be sufficient to allow synaptic terminal remodeling and regeneration. It is possible, however, that cell injury may amplify such a regenerative response.

\section{Implications for retinal transplantation}

The possibility of treating patients with photoreceptor degenerations by transplantation of normal photoreceptor cells has spurred work on a number of experimental models (Turner and Blair, 1986; del Cerro et al., 1988; Silverman and Hughes, 1989a; Ehinger et al., 1991; Gouras et al., 1991). These studies employed developing retinal cells. There are a number of possible advantages to using immature cells in transplantation, including ease of harvesting and satisfactory cell viability (Aramant et al., 1988). One possible drawback, however, is that immature cells must complete their neuroanatomical and functional development in the environment of the mature retina, which might be deficient in certain developmental cues. For example, basic fi- broblast growth factor, which affects rat photoreceptor differentiation in vitro (Hicks and Courtois, 1988, 1992), has been reported to be present in the outer neural retina only during the early postnatal period (Connolly et al., 1991). The advantage of using mature photoreceptors is that they have already completed their differentiation; the challenge, then, becomes effective isolation, survival, and synaptogenesis. Our present and previous work demonstrates that adult photoreceptors are capable of both presynaptic regeneration and formation of functional connections in low-density cell culture (MacLeish and Townes-Anderson, 1988). These results raise the possibility that fully differentiated photoreceptors might reestablish synaptic connections in a mature host retina. Indeed, transplantation of mature photoreceptors has been demonstrated (Silverman and Hughes, 1989b; Gouras et al., 1991; Silverman et al., 1992), although the level of functional incorporation remains to be determined.

\section{References}

Adler R, Lindsey JD, Elsner CL (1984) Expression of cone-like properties by chick embryo neural retina cells in glial-free monolayer cultures. J Cell Biol 99:1173-1178.

Aguayo AJ, Bray GM, Rasminsky M, Zwimpfer T, Carter D, VidalSanz M (1990) Synaptic connections made by axons regenerating in the central nervous system of adult mammals. J Exp Biol 153:199224.

Akagawa K, Barnstable CJ (1986) Identification and characterization of cell types in monolayer cultures of rat retina using monoclonal antibodies. Brain Res 383:110-120.

Araki M, Iida Y, Takctani S, Watanabe K, Ohta T, Saito T (1987) Characterization of photoreceptor cell differentiation in the rat retinal cell culture. Dev Biol 124:239-247.

Aramant R, Seiler M, Turner JE (1988) Donor age influences on the success of retinal grafts to adult rat retina. Invest Ophthalmol Vis Sci 29:498-503.

Attwell D, Wilson M, Wu SM (1984) A quantitative analysis of interactions between photoreceptors in the salamander (Ambystoma) retina. J Physiol (Lond) 352:703-737.

Bader CR, MacLeish PR, Schwartz EA (1978) Responses to light of solitary rod photoreceptors isolated from tiger salamander retina. Proc Natl Acad Sci USA 75:3507-3511.

Buckley K, Kelly RB (1985) Identification of a transmembrane glycoprotein specific for secretory vesicles of neural and endocrine cells. J Cell Biol 100:1284-1294.

Buckley KM, Landis SC (1983) Morphological studies of neurotransmitter release and membrane recycling in sympathetic nerve terminals in culture. J Neurocytol 12:93-116.

Chiquet M, Acklin SE (1986) Attachment of concanavalin-A or extracellular matrix initiates rapid sprouting by cultured leech neurons. Proc Natl Acad Sci USA 83:6188-6192.

Connolly S, Hjelmeland L, LaVail M (1991) Localization of bFGF in developing retinas of normal and RCS rats. Invest Ophthalmol Vis Sci [Suppl] 32:754.

Copenhagen DR, Jahr CE (1989) Release of endogenous excitatory amino acids from turtle photoreceptors. Nature 341:536-539.

Cotman CW, Nieto-Sampedro M (1984) Cell biology of synaptic plasticity. Science 225:1287-1294.

Custer NV (1973) Structurally specialized contacts between the photoreceptors of the retina of the axolotl. J Comp Neurol 151:35-56.

De Camilli P, Harris SM, Huttner WB, Greengard P (1983) Synapsin I (protein I), a nerve terminal-specific phosphoprotein. II. Its specific association with synaptic vesicles demonstrated by immunocytochemistry in agarose-embedded synaptosomes. J Cell Biol 96:13551373.

DeGeorge JJ, Slepecky N, Carbonetto S (1985) Concanavalin A stimulates neuron-substratum adhesion and nerve fiber outgrowth in culture. Dev Biol 111:335-351.

del Cerro M, Notter MF, Wiegand SJ, Jiang LQ, del Cerro C (1988) Intraretinal transplantation of fluorescently labeled retinal suspensions. Neurosci Lett 92:21-26.

Ehinger B, Bergström A, Seiler M, Aramant RB, Zucker CL, Gustavii 
B, Adolph AR (1991) Ultrastructure of human retinal cell transplants with long survival times in rats. Exp Eye Res 53:447-460.

Fekete DM, Barnstable CJ (1983) The subcellular localization of rat photoreceptor-specific antigens. J Neurocytol 12:785-803.

Gouras P, Du J, Gelanze M, Kwun R, Kjeldbye H, Lopez R (1991) Transplantation of photoreceptors labeled with tritiated thymidine into RCS rats. Invest Ophthalmol Vis Sci 32:1704-1707.

Greenough WT, Bailey CH (1988) The anatomy of memory: convergence of results across a diversity of tests. Trends Neurosci 11:142147.

Heuser JE, Reese TS (1973) Evidence for recycling of synaptic vesicle membrane during transmitter relcase at the frog ncuromuscular junction. J Cell Biol 57:315-344.

Hicks D, Barnstable CJ (1987) Different rhodopsin monoclonal antibodies reveal different binding patterns on developing and adult rat retina. J Histochem Cytochem 35:1317-1328.

Hicks D, Courtois Y (1988) Acidic fibroblast growth factor stimulates opsin levels in retinal photoreceptor cells in vitro. FEBS Lett 234: $475-479$.

Hicks D, Courtois Y (1992) Fibroblast growth factor stimulates photoreceptor differentiation in vitro. J Neurosci 12:2022-2034.

Hicks D, Molday RS (1986) Differential immunogold-dextran labeling of bovine and frog rod and cone cells using monoclonal antibodies against bovine rhodopsin. Exp Eye Res 42:55-71.

Hicks D, Sparrow J, Barnstable CJ (1989) Immunoelectron microscopical examination of the surfacc distribution of opsin in rat rod photoreceptor cells. Exp Eye Res 49:13-29.

Hume RI, Role LW, Fischbach GD (1983) Acetylcholine release from growth cones detected with patches of acetylcholine receptor-rich membranes. Nature 305:632-634.

Janetzko A, Zimmermann H, Volknandt W (1989) Intraneuronal distribution of a synaptic vesicle membrane protein: antibody binding sites at axonal membrane compartments and trans-Golgi network and accumulation at nodes of Ranvier. Neuroscience 32:65-67.

Jansen HG, Sanyal S (1984) Development and degeneration of retina in $r d s$ mutant mice: electron microscopy. J Comp Neurol 224:71-84.

Jansen HG, Sanyal S (1987) Synaptic changes in the terminals of rod photoreceptors of albino mice after partial visual cell loss induced by brief exposure to constant light. Cell Tissue Res 250:43-52.

Johnson GD, Davidson R, McNamee K, Russell G, Goodwin D, Holobrow EJ (1982) Fading of immunofluorescence during microscopy: a study of the phenomenon and its remedy. J Immunol Methods 55: 231-242.

Kelly RB, Buckley KM, Burgess TL, Carlson SS, Caroni P, Hooper JE, Katzen A, Moore H-P, Pfeffer SR, Schroer TA (1983) Membrane traffic in neurons and peptide-secreting cells. Cold Spring Harbor Symp Quant Biol 48:697-705.

Kljavin IJ, Reh TA (1991) Muller cells are a preferred substrate for in vitro neurite extension by rod photoreceptor cells. J Neurosci 11 : 2985-2994.

Lasansky A (1973) Organization of the outer synaptic layer in the retina of the larval tiger salamander. Philos Trans R Soc Lond [Biol] 265:471-489.

Laurens II, Williams JW (1917) Photomechanical changes in the retina of normal and transplanted eyes of Amblystoma larvae. J Exp Zool 23:71-83.

Lin SS, Levitan IB (1987) Concanavalin A alters synaptic specificity between cultured Aplysia neurons. Science 237:648-650.

MacLeish PR, Townes-Anderson E (1988) Growth and synapse formation among major classes of adult salamander retinal neurons in vitro. Neuron 1:751-760.

MacLeish PR, Barnstable CI, Townes-Anderson E (1983) Ise of a monoclonal antibody as a substrate for mature neurons in vitro. Proc Natl Acad Sci USA 80:7014-7018.

Mandell JW, Townes-Anderson E, MacLeish PR (1988) Immunocytochemical localization of the synaptic vesicle protein SV2 in cultured adult salamander retinal neurons. Soc Neurosci Abstr 14:804.

Mariani AP (1986) Photoreceptors of the larval tiger salamander retina. Proc R Soc Lond [Biol] 227:483-492.

Matteoli M, Takei K, Perin MS, Südhof TC, De Camilli P (1992) Exo- endocytotic recycling of synaptic vesicles in developing processes of cultured hippocampal neurons. J Cell Biol 117:849-862.

Maycox PR, Link E, Reetz A, Morris SA, Jahn R (1992) Clathrincoated vesicles in nervous tissue are involved primarily in synaptic vesicle recycling. J Cell Biol 118:1379-1388.

Molday RS, Molday LL (1979) Identification and characterization of multiple forms of rhodopsin and minor proteins in frog and bovine rod outer segment disc membranes. J Biol Chem 254:4653-4660.

Poo M, Cone RA (1974) Lateral diffusion of rhodopsin in the photoreceptor membrane. Nature 247:438-441.

Ripps H, Shakib M, MacDonald ED (1976) Peroxidase uptake by photoreceptor terminals of the skate retina. J Cell Biol 70:86-96.

Rivas RJ, Moore HP (1989) Spatial segregation of the regulated and constitutive secretory pathways. J Cell Biol 109:51-60.

Sale WS, Besharse JC, Piperno G (1988) Distribution of acetylated alpha-tubulin in retina and in in vitro-assembled microtubules. Cell Motil Cytoskel 9:243-253.

Sanyal S, Hawkins RK, Jansen HG, Zeilmaker GH (1992) Compensatory synaptic growth in the rod terminals as a sequel to partial photoreceptor loss in the retina of chimaeric mice. Development 114: 797-803.

Schacher SM, Holtzman E, Hood DC (1974) Uptake of horseradish peroxidase by frog photoreceptor synapses in the dark and the light. Nature 249:261-263.

Schaeffer SF, Raviola E (1978) Membrane recycling in the cone cell endings of the turtle retina. J Cell Biol 79:802-825.

Schmied R, Holtzman E (1989) Involvement of the Golgi apparatus in sorting of materials to opposite ends of frog rod retinal photoreceptors. J Neurobiol 20:115-138.

Silverman MS, Hughes SE (1989a) Transplantation of photoreceptors to light-damaged retina. Invest Ophthalmol Vis Sci 30:1684-1690.

Silverman MS, Hughes SE (1989b) Photoreceptor transplantation in inherited and environmentally-induced retinal degeneration: anatomy, immunohistochemistry and function. Prog Clin Biol Res 314: $687-704$.

Silverman MS, Hughes SE, Valentino TL, Liu Y (1992) Photoreceptor transplantation: anatomic, electrophysiologic, and behavioral evidence for the functional reconstruction of retinas lacking photoreceptors. Exp Neurol 115:87-94.

Spencer M, Detwiler PB, Bunt MAH (1988) Distribution of membrane proteins in mechanically dissociated retinal rods. Invest Ophthalmol Vis Sci 29:1012-1020.

Steward O (1989) Reorganization of neuronal connections following CNS trauma: principles and experimental paradigms. J Neurotrauma 6:99-152.

Tixier-Vidal A, Faivre-Bauman A, Picart R, Wiedenmann B (1988) Immunoelectron microscopic localization of synaptophysin in a Golgi subcompartment of developing hypothalamic neurons. Neuroscience 26:847-861.

Townes-Anderson E, MacLeish PR, Raviola E (1985) Rod cells dissociated from mature salamander retina: ultrastructure and uptake of horseradish peroxidase. J Cell Biol 100:175-188.

Tucker RP, Matus AI (1988) Microtubule-associated proteins characteristic of embryonic brain are found in the adult mammalian retina. Dev Biol 130:423-434.

Tucker RP, Binder LI, Matus AI (1988) Differential localization of the high- and low-molecular weight variants of MAP2 in the developing retina. Dev Brain Res 38:313-318.

Turner JE, Blair JR (1986) Newborn rat retinal cells transplanted into a retinal lesion site in adult host eyes. Brain Res 39:91-104.

Valtorta F, Jahn R, Fesce R, Greengard P, Ceccarelli B (1988) Synaptophysin (p38) at the frog neuromuscular junction: its incorporation into the axolemma and recycling after intense quantal secretion. $J$ Cell Biol 107:2719-2730.

Vaughan DK, Fisher SK, Bernstein SA, Hale IL, Linberg KA, Matsumoto B (1989) Evidence that microtubules do not mediate opsin vesicle transport in photoreceptors. J Cell Biol 109:3053-3062.

Young SH, Poo M (1983) Spontaneous release of transmitter from growth cones of embryonic neurones. Nature 305:634-637. 